\title{
Polymorphisms in the glutathione pathway modulate cystic fibrosis severity: a cross-sectional study
}

Fernando Augusto de Lima Marson ${ }^{1,2^{*}}$, Carmen Silvia Bertuzzo ${ }^{2}$, Antonio Fernando Ribeiro ${ }^{1}$ and Jose Dirceu Ribeiro ${ }^{1}$

\begin{abstract}
Background: Cystic fibrosis (CF) clinically manifests with various levels of severity, which are thought to be modulated by mutations in the cystic fibrosis transmembrane conductance regulator gene (CFTR), modifier genes, and the environment. This study verified whether polymorphisms in modifier genes associated with glutathione (GSH) metabolism influence CF severity.

Methods: A cross-sectional study of 180 CF patients was carried out from 2011 to 2012. We analyzed CFTR mutations, polymorphisms (GSTM1 and GSTT1 deletions, GSTP1 + 313A > G, GCLC-129C > T, and GCLC-3506A > G) in modifier genes and CF clinical severity as assessed by 28 clinical and laboratory variables.

Results: Significant associations were found between modifier gene polymorphisms and particular phenotypes or genotype changes. These included GCLC-129C > T with a higher frequency of the Pseudomonas aeruginosa mucoid to CC genotype ( $p=0.044$ ), and GCLC-3506A $>G$ with a higher frequency of the no-mucoid $P$. aeruginosa (NMPA) to AA genotype $(p=0.012$ ). The GSTT1 deletion was associated with a higher frequency of the NMPA to homozygous deletion $(p=0.008)$, GSTP1 $+313 \mathrm{~A}>\mathrm{G}$ with a minor risk of osteoporosis $(p=0.036)$, and patient age $\leq 154$ months ( $p=0.044)$ with the AA genotype. The Bhalla score was associated with GCLC-3506A > G ( $p=0.044)$ and GSTM1/GSTT1 deletion polymorphisms $(p=0.02$ ), while transcutaneous hemoglobin oxygen saturation levels were associated with GSTT1 deletions $(p=0.048)$.
\end{abstract}

Conclusion: CF severity is associated with polymorphisms in GSH pathways and CFTR mutations.

Keywords: Cystic fibrosis, CFTR, GSH, GCLC, GST, Genotype, Phenotype, Modifier genes

\section{Background}

Cystic fibrosis (CF) presents with broad phenotypic variability, even in patients with identical mutations in the causative gene, cystic fibrosis transmembrane conductance regulator $(C F T R)$ [1]. Explanations for this include environmental factors [2], medical management [3], nutritional status [4], emotional maladjustments [5], socioeconomic status [3], CFTR mutations [1], and modifier genes [1,3,6]. In this context, CF modifier genes have been studied with

\footnotetext{
* Correspondence: fernandolimamarson@hotmail.com

${ }^{1}$ Center for Investigation in Pediatrics, Faculty of Medical Sciences, University of Campinas. Tessália Vieira de Camargo, 126. Cidade Universitária "Zeferino Vaz", CEP: 13083-887 Campinas, São Paulo, Brazil

${ }^{2}$ Department of Medical Genetics, Faculty of Medical Sciences, University of Campinas. Tessália Vieira de Camargo, 126. Cidade Universitária "Zeferino Vaz", CEP: 13083-887 Campinas, São Paulo, Brazil
}

the aim of increasing chlorine transport and/or controlling pulmonary inflammation and infection [6-9].

Our group studied CF severity in association with several modifier genes including polymorphisms in the genes: $M B L-2$, TGF- $\beta 1, C D 14$ [10], ACE [11], ADRB2 [12], TCF7L2 [13], ADRA2A [14], COX-2 [15] and IFRD1 [16]. These polymorphisms were associated with clinical variables including lung and digestive disease.

Glutathione (GSH) is a tripeptide composed of Lcysteine, L-glutamic acid, and glycine. It is a crucial part of the intracellular defense system, which protects the epithelium against the injuries and inflammation [17] common to CF that are caused by oxidation [18]. As polymorphisms can alter the GSH metabolic pathway, genetic variations of this pathway have previously been studied in association with CF [19-21].

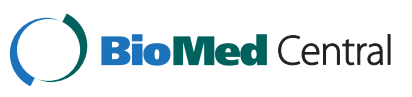


The glutathione S-transferase (GST) family of enzymes comprises proteins with distinct genetic origins that form a detoxification system, which protects the human body against electrophilic compounds and oxidative stress [22]. The GST protein is responsible for combining compounds that cause oxidative stress with GSH. It is therefore possible that GST polymorphisms are involved in CF severity $[18,22]$, especially with regard to pulmonary disease.

Genetic variants of the GST genes include glutathione S-transferase mu 1 (GSTM1) located on chromosome 1p13.3, and glutathione S-transferase theta 1 (GSTT1) on chromosome 22q11.23 [23], which both exhibit polymorphic deletions [22,24]. The null GST allele does not encode a GST protein, so homozygous genotypes are associated with increased CF clinical severity [25,26]. The glutathione S-transferase pi gene (GSTP1) on chromosome 11 13 [23] is associated with xenobiotic metabolism and susceptibility to cancer and other diseases [22]. Its most commonly studied polymorphism is an $\mathrm{A} \rightarrow \mathrm{G}$ base exchange at the +313 position (substituting isoleucine by valine at codon 105) [27].

The glutamate-cysteine ligase, catalytic subunit gene (GCLC) on chromosome 6p12 [23] encodes the catalytic subunit of glutamate-cysteine ligase (GCL), which is the first limiting enzyme in GSH synthesis [28]. The GCL holoenzyme is a heterodimer of approximately $104 \mathrm{kDa}$ composed of catalytic-GCLC and regulatory-GCLR subunits [18]. The $-129 \mathrm{C}>\mathrm{T}$ and $-3506 \mathrm{~A}>\mathrm{G}$ polymorphisms of $G C L C$ are located in the promoter region and are responsible for reduced production of GSH $[18,28]$.

Of these genes, GSTP1 is associated with hepatic disease [19] and infection [20], GSTM1 with greater CF clinical severity [21], GSTT1 with no CF clinical variables, while GCLC has not been previously studied in relation to CF. However, as the action of the GSH protein is closely related to that of CFTR [29], it is conceivable that GCLC and GST polymorphisms influence CF severity [19-21,26,30]. This study therefore aimed to determine whether genetic polymorphisms in the GSH metabolic pathway are associated with CF severity under different phenotypes of the disease.

\section{Methods}

This cross-sectional study was conducted in a university center for CF care between 2011 and 2012. Two hundred and fifteen patients were selected for the study, of which 35 were excluded for not signing the consent form or because of a lack of clinical data for statistical analysis. CF diagnosis was confirmed if levels of chloride in the sweat exceeded $60 \mathrm{mEq} / \mathrm{L}$ and by CFTR mutation screening when possible. CF patients, with no identified CFTR mutation or with one CFTR mutation screened, were classified as CF disease, considering: (i) all patients had levels of chloride in the sweat exceeded $60 \mathrm{mEq} / \mathrm{L}$; (ii) CF clinical symptoms were diagnosed in all patients as: chronic obstructive pulmonary disease, bacteria in sputum, spirometry with obstruction values for forced expiratory volume in the first second $\left(\mathrm{FEV}_{1} \%\right)$, associated comorbidities (i.e. osteoporosis, nasal polyps, diabetes mellitus and pancreatic insufficiency); (iii) the dosage of active CFTR in epithelium via rectal biopsy was performed - all patients included had abnormal values for biopsy - absence of active CFTR was found; (iv) nasal potential was realized in some patients - all values were changed - but the comparison was not performed, taking into account a control standard curve, being an inconclusive data. By this method was possible to exclude Cystic Fibrosis Related Diseases.

No patients were diagnosed by a neonatal screening test. Patient DNA was obtained by phenol-chloroform extraction and $50 \mathrm{ng} / \mathrm{mL}$ was used for analysis as evaluated by a GE NanoVue ${ }^{\mathrm{Tm}}$ Spectrophotometer (GE Healthcare Biosciences, Pittsburgh, PA, USA).

\section{Clinical variables}

Several clinical variables were employed, including Shwachman-Kulczycki, Kanga and Bhalla clinical scores [31]; body mass index (BMI) [for patients older than 19 years, the $\mathrm{BMI}=$ weight $/(\text { height })^{2}$ formula was used, while remaining patients used the WHO ANTHRO program (children 0-5 years of age) or the WHO ANTHRO PLUS program (children 5-19 years of age)]; patient's age ( $\leq 154$ and $>154$ months); time to diagnosis $(\leq 24$ and $>24$ months); time of first clinical symptoms (digestive: $\leq 3$ and $>3$ months; pulmonary: $\leq 6$ and $>6$ months); time to first colonization by Pseudomonas aeruginosa ( $\leq 31$ and $>31$ months); bacteria in the respiratory airways: mucoid $P$. aeruginosa and no mucoid $P$. aeruginosa, Achromobacter xylosoxidans, Burkholderia cepacia and Staphylococcus aureus - the positive status was evaluated considering chronic infection (patients in whom more than $50 \%$ of the preceding 12 months was culture positive) + intermittent infection (patients with less than $50 \%$ of cultures positive). A patient was negative considering as free of bacterium (when no bacterium was grown from samples in the previous 12 months, despite a history of prior colonization) + never infected (patients in whom the bacterium) has never been cultured, i.e. this consensus was formulated for $P$. aeruginosa, but in our data was used for all bacteria [32]; transcutaneous hemoglobin oxygen saturation $(\mathrm{SpO} 2)$ and spirometry variables.

Spirometry was performed in patients older than seven years of age with the CPFS/D spirometer (MedGraphics, Saint Paul, MN, USA) and data were recorded using the PF BREEZE software version 3.8B for Windows 95/98/NT [33]. The following variables were included: forced vital capacity $[\mathrm{FVC}(\%)]$; forced expiratory volume in the first second $\left[\mathrm{FEV}_{1}(\%)\right]$, the ratio between $\mathrm{FEV}_{1}$ and $\mathrm{FVC}(\%)$ $\left[\mathrm{FEV}_{1} / \mathrm{FVC}(\%)\right]$; and forced expiratory flow between 25 
and $75 \%$ of the FVC $\left[\mathrm{FEF}_{25-75} \%\right]$. The data was analyzed considering international curves values for spirometry tests $[34,35]$.

The comorbidities analyzed were nasal polyps, osteoporosis, meconium ileus, diabetes mellitus, and pancreatic insufficiency. This study was approved by the Institutional Ethics Committee from the Faculty of Medical Sciences, University of Campinas (\#528/2008), and all included patients or their parents signed a consent form before beginning the study.

\section{CFTR mutation identification}

CFTR mutation identification was performed by polymerase chain reaction (PCR) for F508del and the fragment-length polymorphism method for G542X, R1162X, R553X, G551D, and N1303K mutations. Some CF mutations were identified by sequencing or Multiplex Ligation-dependent Probe Amplification (MLPA) analysis: S4X, 2183A > G, 1717-G > A, and I618T. A MegaBace $1000^{\circ}$ sequencer (GE Healthcare Biosciences) was used for sequencing and MLPA.

The CFTR genotype was used as a correction factor for statistical analysis. All class I, II or III mutations, but not class IV mutations (P205S and R334W), identified were included in statistical analysis.

\section{Identification of polymorphisms associated with GSH metabolic pathway genes}

Polymorphism identification was carried out using PCR analysis. For GSTM1 and GSTT1 genes, a multiplex PCR reaction was performed using the CYP1A1 gene as an internal amplification control [36]. GCLC-129C > $\mathrm{T},-3506 \mathrm{~A}>\mathrm{G}[18,28]$ and GSTP1 + 313A > G [27] polymorphisms were identified by PCR followed by enzymatic digestion.

\section{Statistical analysis}

Statistical analysis was performed using Statistical Package for Social Sciences (SPSS) software version 21.0 (SPSS Inc., Chicago, IL, USA), Epi Info version 6.0 [37] and R version 2.12 (Comprehensive R Archive Network, 2011). GPower 3.0.3.1 software [38] was used to calculate the statistical power, which was required to be above $80 \%$ for analysis.

Statistical tests included the analysis of variance (ANOVA) and the chi-square $\left(x^{2}\right)$ test (Odds Ratio -OR) for GSTM1 and GSTT1, and the $t$-test and Fisher's exact test for $G C L C-129 \mathrm{C}>\mathrm{T}, G C L C-3506 \mathrm{~A}>\mathrm{G}$ and GSTP1 + 313A > G polymorphisms. To avoid spurious data caused by the performance of multiple tests [39], the significance level $(\alpha)$ was adjusted by the Bonferroni correction $(\alpha$ corrected $=0.05 /$ number of tests $\rightarrow 0.05 / 4=$ $0.0125)$. The value of $\alpha$ was corrected considering clinical marker analysis of the same group of patients, taking into account, the CFTR mutation genotype.

Data distribution showing a high standard deviation was analyzed in groups distributed according to median value. Variables that were adjusted by median to short (more severe) and longtime were patient's age, time to diagnosis, onset of pulmonary and digestive symptoms, and time to the first isolation of $P$. aeruginosa.

Analyses were performed of four cohorts: (i) all patients with CF ( $\mathrm{n}=180)$; (ii) patients with no identified CFTR mutation $(\mathrm{n}=44)$; (iii) patients with an identified mutant CFTR allele (Class I, II and/or III) ( $\mathrm{n}=51)$; and (iv) patients with two identified CFTR mutations (Class I, II and/or III) $(\mathrm{n}=85)$. For (ii) and (iii) groups, a second analysis was performed. In this case, CF patients with pancreatic sufficiency (PS) were excluded. Patients with mutations Class I, II and III for CFTR gene have severe disease, strongly associated with pancreatic insufficiency (PI). Excluding PI patients was a method to associated different CFTR mutation groups with no atypical CF - associated less severe mutation (Class IV, V and VI). After exclusion, we have in (ii) and (iii) groups, respectively, 35 and 43 CF patients.

\section{Results and discussion}

One of the most intriguing aspects of CF is that patients with the same CFTR genotype can present with phenotypic differences [40]. At our CF center, all patients receive free medication provided by the state, have a similar socioeconomic status, share similar Class I, II and/or III mutations, receive support from the Cystic Fibrosis Association (http://www.fibrocis.org.br/), and there are no severe cases of malnutrition. This therefore makes our sample more phenotypically homogeneous for studies involving gene modulation characteristics.

Variations in CF severity can be associated with a modifier gene, such as those associated with oxidative stress [19-21,26,30] that are related to chronic obstructive pulmonary disease (COPD) [18]. The COPD pathophysiology is similar, in some aspects, to CF in that it involves cellular responses, inflammatory mediators, and oxidative stress [41]. However, there is no mention in the scientific literature of GCLC polymorphisms as clinical modulators of CF severity, and is necessary new studies to illuminate about GST genes and CF severity.

One of the main functions of GSH is to detoxify xenobiotics and their metabolites, and this function is dependent on GST proteins. The GST gene family has been linked with several diseases [22], as GSTM1, GSTT1 and GSTP1 polymorphisms were found to be associated with cancer, drugs, chemotherapy resistance [42], and respiratory diseases such as asthma [30]. For example, expression of the variant form of GSTP1 (where isoleucine is substituted for valine at codon 105) results in lower enzymatic activity, which is a risk 
factor for the development of cancer and pulmonary diseases such as CF [43].

The effects of GSTM1, GSTT1 and GSTP1 polymorphisms on spirometry were previously investigated in 1,940 children (aged 8-11 years) [44]. The null GSTM1 genotype was associated with a decrease in annual $\mathrm{FVC}(\%)$ and $\mathrm{FEV}_{1}(\%)$ gain; likewise, homozygosity for the GSTP1 allele was linked with slower spirometric gain for the same markers. The GSTM1 and GSTP1 genotypes therefore appear to be associated with spirometric evolution, and could increase the severity of diseases of pulmonary obstruction, depending on the genotype and gene combination.

Table 1 shows the GCLC, GSTM1, GSTT1 and GSTP1 polymorphism distribution according to genotype in the present study. The $-129 \mathrm{C}>\mathrm{T}$ polymorphism in the promoter region of GCLC stimulates different responses to oxidative stress by decreasing GSH production and reducing cellular antioxidant capacity [45]. In the present study, it was associated with a higher frequency of the mucoid $P$. aeruginosa to CC genotype for GCLC-129C > T polymorphism in patients with one CFTR mutation identified (Table 2; $p=0.044$ ). This association may be related to the lower GCLC protein expression in CC genotypes, which reduces circulating GSH levels. The T allele is also associated with increased GSH expression, as described in protein expression studies on cardiovascular disease [45]. In the cited literature, we only found one study that associated the GCLC polymorphism with CF severity. In this previous study, the GAG micro-satellite GCLC polymorphism was analyzed in $440 \mathrm{CF}$ patients, and CFTR mutations of lower gravity and highest number of GAG repeats in the GCLC gene were associated with higher values of $\mathrm{FEV}_{1}(\%)[20]$.
The GCLC-3506A > G polymorphism is not in HardyWeinberg equilibrium as shown in Table 3, which also shows the complete genotypic characteristics of GCLC, GSTM1, GSTT1, and GSTP1 polymorphisms and CFTR mutations in CF patients with regard to chromosomal position, polymorphism location within the gene, and minor allele frequency. GCLC-3506A > G was associated with a higher frequency of the no mucoid $P$. aeruginosa to AA genotype, and with a lower frequency of the no mucoid $P$. aeruginosa to AG + GG genotype group in patients with one CFTR mutation identified (Table 2; $p=0.012$ ) and higher Bhalla score values (without taking CFTR mutation into account; $p=0.044$ ).

The Bhalla score is associated with an impairment of the pulmonary parenchyma structure and higher values characterize major changes in thoracic tomography. Unexpectedly, we also found that the greatest expression of the A allele in the GCLC-3506A > G polymorphism did not protect against no mucoid $P$. aeruginosa colonization. However, protection against lung deterioration was evident when we considered the Bhalla score. This score was also associated with GSTM1/GSTT1 deletions $(p=0.02)$, with a lower frequency of heterozygous compared with homozygous deletions. Moreover, the GSTT1 deletion was found to be associated with $\mathrm{SpO} 2$ values $(p=0.048$; Table 4).

GCLC haplotype analysis for $G C L C-129 \mathrm{C}>\mathrm{T}$ and GCLC-3506A > G showed association for A. xylosoxidans and $\mathrm{CC}+\mathrm{AA}$ genotypes $(\mathrm{OR}=17.9 ; \mathrm{CI} 95 \%=2.781-411.6$; Table 5).

The present study found that the AA genotype of the GSTP1 + 313A > G polymorphism was associated with a low risk of osteoporosis $(p=0.036$; with two CFTR mutations identified) as a protective factor and with young

Table 1 Distribution of GCLC, GSTM1, GSTT1 and GSTP1 polymorphisms

\begin{tabular}{|c|c|c|c|c|c|c|c|}
\hline \multirow{2}{*}{$\frac{\text { Gene }}{G C L C}$} & \multicolumn{2}{|c|}{ Polymorphism } & \multicolumn{2}{|c|}{ Genotypes ( $\mathrm{N}$ analyzed and \%) } & \multicolumn{2}{|c|}{ Grouping ( $\mathrm{N}$ analyzed and \%) } & \multirow{2}{*}{$\frac{\text { Total }}{181(100 \%}$} \\
\hline & $-129 \mathrm{C}>\mathrm{T}^{\mathrm{a}}$ & $\mathrm{CC}$ & CT & $\pi$ & $\mathrm{CC}$ & $C T+\pi$ & \\
\hline & & $145(80.11 \%)$ & $29(16.02 \%)$ & $7(3.87 \%)$ & $145(80.11 \%)$ & $36(19.89 \%)$ & \\
\hline & $-3506 \mathrm{~A}>\mathrm{G}^{\mathrm{b}}$ & $\mathrm{AA}$ & $A G$ & GG & $\mathrm{AA}$ & $A G+G G$ & $181(100 \%)$ \\
\hline & & $119(65.75 \%)$ & $56(30.94 \%)$ & $6(3.31 \%)$ & $119(65.75 \%)$ & $62(35.25 \%)$ & \\
\hline \multirow[t]{2}{*}{ M1 } & Deletion $^{c}$ & - & + & & & & $181(100 \%)$ \\
\hline & & $73(40.33 \%)$ & $108(59.67 \%)$ & & & & \\
\hline \multirow[t]{2}{*}{ T1 } & Deletion $^{d}$ & - & + & & & & $181(100 \%)$ \\
\hline & & $63(34.81 \%)$ & $118(65.19 \%)$ & & & & \\
\hline \multirow[t]{2}{*}{$M 1 / T 1$} & Deletion & $-1-$ & $+/-$ and $-/+$ & $+/+$ & & & $181(100 \%)$ \\
\hline & & $19(10.50 \%)$ & $99(54.70 \%)$ & $63(34.80 \%)$ & & & \\
\hline \multirow[t]{2}{*}{ GSTP1 } & $+313 \mathrm{~A}>\mathrm{G}^{\mathrm{f}}$ & AA & $A G$ & GG & $\mathrm{AA}$ & $A G+G G$ & $181(100 \%)$ \\
\hline & & $98(54.14 \%)$ & $74(40.88 \%)$ & $9(4.98 \%)$ & $98(54.14 \%)$ & 83 (45.86\%) & \\
\hline
\end{tabular}

GSTM1, Glutathione S-transferase Mu; GST1, Glutathione S-transferase Theta 1; GSTP1, Glutathione S-transferase Pi 1; GCLC, Glutamate-cysteine ligase, catalytic subunit; N, Sample size; -, Null allele; +, Expressed allele.

The statistical association, taking into account the CFTR mutation groups, with the polymorphisms distribution was by $\mathrm{p}$-values in the table: ${ }^{\mathrm{a}} 0.880$ (GCLC-129C > T); ${ }^{\mathrm{b}} 0.075$ GCLC-3506A > G); ${ }^{\mathrm{c}} 0.969$ (M1); ${ }^{\mathrm{d}} 0.088(\mathrm{~T} 1) ;{ }^{\mathrm{e}} 0,329(\mathrm{GSTP} 1+313 \mathrm{~A}>\mathrm{G})$. 
Table 2 Polymorphisms in modifier genes associated with categorical variables of cystic fibrosis severity

\begin{tabular}{|c|c|c|c|c|c|c|c|c|}
\hline \multirow{3}{*}{$\begin{array}{l}\text { CFTR group } \\
\text { One CFTR mutation identified }\end{array}$} & \multirow{3}{*}{$\begin{array}{l}\text { Polymorphism } \\
\text { GCLC-129C > T }\end{array}$} & \multirow[t]{3}{*}{ Genotype } & \multicolumn{3}{|c|}{ Variable } & \multirow[t]{3}{*}{$p^{c}$} & \multirow[t]{3}{*}{ OR } & \multirow[t]{3}{*}{$\mathrm{Cl}(5-95 \%)$} \\
\hline & & & \multicolumn{3}{|c|}{ PAM } & & & \\
\hline & & & Presence & Absence & Total & & & \\
\hline & & $\mathrm{CC}$ & 25 & 17 & 42 & \multirow[t]{2}{*}{0.044} & 11.27 & $1.6-272.6$ \\
\hline & & $C T+T T$ & 1 & 8 & 9 & & - & - \\
\hline & \multirow[t]{4}{*}{ GCLC-3506A > G } & & \multicolumn{3}{|c|}{ PANM } & & & \\
\hline & & & Presence & Absence & Total & & & \\
\hline & & $\mathrm{AA}$ & 28 & 9 & 37 & 0.012 & 7.408 & $1.905-33.43$ \\
\hline & & $A G+G G$ & 4 & 10 & 14 & & - & - \\
\hline \multirow[t]{4}{*}{ No mutation identified } & \multirow[t]{4}{*}{ GSTT1 gene deletion } & & \multicolumn{3}{|c|}{ PANM } & & & \\
\hline & & & Presence & Absence & Total & & & \\
\hline & & Not expressed & 13 & 9 & 21 & 0.008 & 7.895 & $2.095-34.96$ \\
\hline & & Expressed & 4 & 23 & 27 & & - & - \\
\hline \multirow[t]{4}{*}{ One CFTR mutation identified + IP } & \multirow[t]{4}{*}{ GSTM1 gene deletion } & & \multicolumn{3}{|c|}{ Digestive symptoms } & & & \\
\hline & & & \multicolumn{3}{|c|}{$<6$ months $\geq 6$ months } & & & \\
\hline & & Not expressed & 3 & 12 & 15 & 0.032 & 0.134 & 0.023-0.606 \\
\hline & & Expressed & 14 & 7 & 21 & & - & - \\
\hline \multirow[t]{4}{*}{ Two mutations identified } & \multirow[t]{4}{*}{ GSTP1 + 313A > G } & & \multicolumn{3}{|c|}{ Osteoporosis } & & & \\
\hline & & & Presence & Absence & Total & & & \\
\hline & & AA & 2 & 42 & 44 & 0.036 & 0.141 & $0.028-0.687$ \\
\hline & & $A G+G G$ & 9 & 26 & 35 & & - & - \\
\hline \multirow[t]{4}{*}{ Without taking CFTR mutation into account } & & & \multicolumn{3}{|c|}{ Age (months) } & & & \\
\hline & & & $\leq 154$ & $>154$ & Total & & & \\
\hline & & AA & 58 & 39 & 97 & 0.044 & 2.198 & $1.208-4.037$ \\
\hline & & $A G+G G$ & 33 & 49 & 82 & & - & - \\
\hline
\end{tabular}

Statistical analysis was performed by Fisher's exact test. CFTR, Cystic fibrosis transmembrane regulator; GCLC, Glutamate-cysteine ligase catalytic subunit; GSTM1, Glutathione S-transferase mu 1; GSTT1, Glutathione S-transferase theta 1; GSTP1, Glutathione S-transferase Pi 1; PI, Pancreatic insufficiency; PAM, Pseudomonas aeruginosa mucoid; PANM, Pseudomonas aeruginosa no mucoid; $\mathrm{p}^{c}, P$-value corrected by Bonferroni test; $\mathrm{OR}$, Odds ratio; $\mathrm{Cl}$, Confidence interval.

age $\leq 154$ months $(p=0.044$; without taking the CFTR gene into account) as a risk factor. The $\mathrm{G}$ allele, however, is responsible for increased GSTP1 expression. The presence of osteoporosis is influenced by several different factors, including mutations in the CFTR gene, the environment, modifier genes, and increased life expectancy [46]. In this context, in our data, the A allele is protective against osteoporosis, and is increased among young patients with unresolved CFTR mutation genotype. The osteoporosis frequency is shown in Table 6.

The role of the GSTP1 polymorphism in CF hepatic disease has previously been analyzed [19]. The authors noted that CFTR protein expression was limited in liver epithelium; however, recent discoveries indicate that CFTR modulates the transport of GSH, creating a dysfunction in the antioxidant defense [47]. Of the liver detoxifying enzymes, GST plays a major role in protection against oxidative stress. The impact of GSTM1 and GSTP1 was also previously assessed in $106 \mathrm{CF}$ patients where it was verified that the frequency of the GG genotype for the GSTP1 + 313A > G polymorphism was significantly higher in CF patients with hepatic disease. This genotype was associated with an eight-fold increase in hepatic disease risk in patients younger than six years of age. These findings suggest that the identification of this polymorphism may have prognostic and awareness values for the treatment of CF patients with hepatic disease.

Considering the importance of the glutathione transport versus CFTR protein-mediated, patients with residual CFTR protein expression would have better performance in the extracellular oxidative stress response being favorable for the passage of GSH to the outside by residual CFTR activity. However, CF patients with two mutations screened in CFTR gene have principally alternate routes for the passing of GSH. Even taking into account that the most of GSH is transferred to the external environment via CFTR, in cases of residual CFTR (mutations Class IV, $\mathrm{V}$ and VI) would be modified slightly in relation to the GSH activity, since it is known that under 5\% of CFTR expression occurs for minor severe CFTR mutations Classes, and approximately $65 \%$ of GSH passage occurs via CFTR, we had a percentage response to the GSH presence in external environment of at most $3.25 \%$ in cases of residual CFTR. Considering this factor, the analysis excluding the 
Table 3 Genotyping of GCLC, GSTM1, GSTT1, and GSTP1 polymorphisms and CFTR mutations

\begin{tabular}{|c|c|c|c|c|c|c|}
\hline Gene & Chromosomal position & Location & Polymorphism & MAF & HWE & $p$-value \\
\hline GCLC, rs17883901 & $6 \mathrm{p} 12$ & Promoter region & $C>T$ & 0.12 & 9.97 & $<0.005$ \\
\hline GCLC, rs 137852340 & $6 p 12$ & Promoter region & $A>G$ & 0.19 & 0.04 & $>0.05$ \\
\hline GSTP1, rs1695 & $11 q 13$ & Exon & $A>G$ & 0.25 & 1.11 & $>0.05$ \\
\hline$\overline{\text { GSTM1 }}$ & $1 \mathrm{p} 13.3$ & & Deletion & & & \\
\hline GSTT1 & $22 q 11.23$ & & Deletion & & & \\
\hline CFTR mutation & $\mathrm{N}$ & \multicolumn{5}{|c|}{ Frequency } \\
\hline F508del/F508del & 57 & \multicolumn{5}{|c|}{$31.67 \%$} \\
\hline F508del/G542X & 12 & \multicolumn{5}{|c|}{$6.67 \%$} \\
\hline F508del/R1162X & 5 & \multicolumn{5}{|c|}{$2.78 \%$} \\
\hline F508del/N1303K & 4 & \multicolumn{5}{|c|}{$2.22 \%$} \\
\hline F508del/R553X & 1 & \multicolumn{5}{|c|}{$0.56 \%$} \\
\hline F508del/S4X & 1 & \multicolumn{5}{|c|}{$0.56 \%$} \\
\hline F508del/1717-1G > A & 1 & \multicolumn{5}{|c|}{$0.56 \%$} \\
\hline G542X/R1162X & 1 & \multicolumn{5}{|c|}{$0.56 \%$} \\
\hline G542X/I618T & 1 & \multicolumn{5}{|c|}{$0.56 \%$} \\
\hline $\mathrm{G} 542 X / 2183 A>G$ & 1 & \multicolumn{5}{|c|}{$0.56 \%$} \\
\hline R1162X/R1162X & 1 & \multicolumn{5}{|c|}{$0.56 \%$} \\
\hline F508del/- & 45 & \multicolumn{5}{|c|}{$25.00 \%$} \\
\hline G542X/- & 5 & \multicolumn{5}{|c|}{$2.78 \%$} \\
\hline R1162X/- & 1 & \multicolumn{5}{|c|}{$0.56 \%$} \\
\hline$-1-$ & 44 & \multicolumn{5}{|c|}{$24.45 \%$} \\
\hline
\end{tabular}

MAF, Minor allele frequency; HWE, Hardy Weinberg Equilibrium; ${ }^{a}$-value for Hardy-Weinberg Equilibrium; $\mathrm{N}$, Number of patients; -, No identified CFTR mutation.

presence of PI patients enables better grouping of patients and optimizes the response of the associations found in our study.

Most studies analyzing the GSTP1 gene related it to cancer and other diseases $[22,30,44,48]$. For example, the AA genotype of the GSTP1 + 313A > G polymorphism was shown to offer protection against asthmatic symptoms [22]. Indeed, the GSTP1 polymorphism was not previously found to affect pulmonary function in CF patients [30]. In an analysis of different genes involved in GST, there were no differences in GST activity and antioxidant levels observed between CF patients and controls. However, GST activity was lower in P. aeruginosa-infected CF children with severe clinical symptoms, as was the frequency of the GSTP1+ $313 \mathrm{~A}>\mathrm{G}$ polymorphism AA genotype in uninfected (75\%) compared with infected (33\%) children [21]. It is possible that GST activity and GSTP1 genotype play an important role in $P$. aeruginosa infection in CF patients. In support of this, the G allele of the GSTP1 gene appears to be associated with an increased risk of severe pulmonary disease [21]. However, in a previous investigation into GSTM1 and GSTP1 polymorphisms in patients with CF and COPD, no significant associations were found between GSTM1 activity and pulmonary disease severity. An analysis of genotypic combinations for GSTM1 and GSTP1 polymorphic loci showed that changes in GSTP1 activities

Table 4 Polymorphisms in modifier genes associated with numerical variables of cystic fibrosis severity

\begin{tabular}{|c|c|c|c|c|c|c|c|c|}
\hline CFTR group & Variable & Polymorphism & Genotype & $\mathbf{N}$ & Mean & SD & SEM & $p$ - value corrected \\
\hline \multirow{2}{*}{$\begin{array}{l}\text { Without taking CFTR mutation } \\
\text { into account }\end{array}$} & \multirow[t]{2}{*}{ Bhalla score ${ }^{a}$} & \multirow[t]{2}{*}{ GCLC-3506A > G } & AA & 94 & 19.70 & 6.007 & 0.620 & \multirow[t]{2}{*}{0.044} \\
\hline & & & $A G+G G$ & 43 & 17.00 & 5.033 & 0.768 & \\
\hline \multirow[t]{5}{*}{ No mutation identified } & \multirow[t]{2}{*}{$\mathrm{SpO}^{\mathrm{a}}$} & \multirow[t]{2}{*}{ GSTT1 deletion } & Not expressed & 15 & 96.13 & 2.232 & 0.576 & \multirow[t]{2}{*}{0.048} \\
\hline & & & Expressed & 29 & 93.17 & 5.245 & 0.974 & \\
\hline & \multirow[t]{3}{*}{ Bhalla score $^{b}$} & \multirow[t]{3}{*}{ GSTM1/GSTT1 deletions } & $-/-$ & 4 & 14.75 & 1.258 & 0.629 & \multirow[t]{3}{*}{0.02} \\
\hline & & & $+/-$ and $-/+$ & 21 & 6.900 & 6.610 & 1.442 & \\
\hline & & & $+/+$ & 9 & 15.33 & 7.533 & 2.511 & \\
\hline
\end{tabular}

${ }^{\mathrm{a}}$ Using Student's $t$-test; ${ }^{\mathrm{b}}$ Using analysis of variance.

CFTR, Cystic fibrosis transmembrane regulator; SpO2, Hemoglobin oxygen saturation in the blood; -, Null allele; +, Expressed allele; N, Number of patients. 
Table 5 GCLC-129C > T and GCLC-3506A > G haplotype polymorphisms in modifier genes associated with categorical variables of cystic fibrosis severity

\begin{tabular}{|c|c|c|c|c|c|c|c|c|c|}
\hline \multirow[t]{2}{*}{ CFTR group } & \multirow[t]{2}{*}{$\begin{array}{l}\text { PI taking } \\
\text { into account }\end{array}$} & \multirow[t]{2}{*}{ Haplotype } & \multirow[t]{2}{*}{ Genotype } & \multicolumn{3}{|c|}{$\begin{array}{c}\text { Variable } \\
\text { AX }\end{array}$} & \multirow[t]{2}{*}{$p^{c}$} & \multirow[t]{2}{*}{ OR } & \multirow[t]{2}{*}{$\mathrm{Cl}(5-95 \%)$} \\
\hline & & & & Presence & Absence & Total & & & \\
\hline \multirow{4}{*}{$\begin{array}{l}\text { Two mutation } \\
\text { identified }\end{array}$} & \multirow[t]{4}{*}{ No } & \multirow[t]{4}{*}{ GCLC-129C > T + GCLC-3506A > G } & $C C+A A$ & 10 & 26 & 36 & & 17.9 & $2.781-411.6$ \\
\hline & & & $\mathrm{CC}+(\mathrm{AG}$ or $\mathrm{GG})$ & 1 & 30 & 31 & 0.024 & 0.149 & $0.007-0.959$ \\
\hline & & & $(\mathrm{CT}$ or $\mathrm{TT})+\mathrm{GG}$ & 0 & 13 & 13 & & - & - \\
\hline & & & $\pi+G G$ & 0 & 5 & 5 & & - & - \\
\hline
\end{tabular}

Statistical analysis was performed by $\mathrm{X}^{2}$ test. CFTR, Cystic fibrosis transmembrane regulator; GCLC, Glutamate-cysteine ligase catalytic subunit; PI, Pancreatic insufficiency; AX, Achromobacter xylosoxidans; $\mathrm{P}^{\mathrm{c}}, \mathrm{P}$-value corrected by Bonferroni test; OR, Odds ratio; $\mathrm{Cl}$, Confidence interval.

produced adverse effects in patients with COPD. Although GSTM1 gene deletions may not themselves be implicated in pathogenesis, they may aggravate the disease in combination with GSTP1 polymorphisms. Perhaps the strongest performance for the GSTP1 gene in CF may result from the primary expression of this GST in the airways [48].

The present study showed that the homozygous deletion in GSTT1 was a no mucoid $P$. aeruginosa risk factor in the no CFTR mutation group $(p=0.008$; Table 2$)$ and a protective factor for low values of SpO2. GSTT1 expression is likely to act in the inflammatory response of the pulmonary parenchyma. As chronic airway infection by no mucoid $P$. aeruginosa is associated with greater clinical severity [49], the GSTT1 polymorphism may be associated with the presence of $P$. aeruginosa through different mechanisms, including a low antioxidant response leading to further pulmonary degradation and the formation of a favorable environment for no mucoid $P$. aeruginosa colonization or infection.

The mechanism of gene action that determines which bacteria can colonize the lungs of CF patients is not fully understood. Similarly, it is also unclear which microorganisms are risk factors for the disease. Therefore, confirmation of a gene acting as modulator of an important metabolic pathway, such as GSH, may open up novel ways to identify the genetic factors that determine the severity of pulmonary disease. Future pharmacogenetic studies could then use this knowledge to provide new $\mathrm{CF}$ therapies.

Many previous studies have revealed that polymorphisms of GSTM1 and GSTT1 are associated with cancer $[22,24,50,51]$, but few have been conducted in CF. Fiftythree children with CF were studied by Hull and Thomson [26], of which 26 with the GSTM1 null allele had a significantly lower Shwachman-Kulczycki score. This supports the hypothesis that inflammation in CF contributes to tissue injury. Indeed, GSTM1 null alleles can be a risk factor for pulmonary diseases in individuals with a reduced ability to deal with oxidants. There is also evidence that a high level of oxidative stress in the lungs of CF patients is caused by the release of reactive oxygen species by neutrophils [26]. In the present study, we found that expression of only one allele of GSTM1 and GSTT1 polymorphisms was associated with a low Bhalla score in patients with no CFTR mutation identified.

An interesting aspect was the high frequency of PS patients. The presence of PS occurred at exactly $20 \%$ of the sample. However, there was no difference distribution between the groups of patients with CF taking into account CFTR mutations groups $(p=0.621)$. Patients with two mutations identified in CFTR gene had $22.36 \%$ $(19 / 85)$ of PS, values close to the other groups of patients [one identified mutation and no mutation identified with, respectively, $15.7 \%(8 / 51)$ and $20.5 \%(9 / 44)]$.

Table 6 Age's distribution and osteoporosis among CFTR mutation groups

\begin{tabular}{|c|c|c|c|c|c|c|c|c|c|c|c|}
\hline \multirow[t]{2}{*}{ Pancreatic status } & \multirow[t]{2}{*}{ Groups } & \multirow[t]{2}{*}{$\mathbf{N}$} & \multirow[t]{2}{*}{$\begin{array}{c}\text { Mean } \\
\text { (months) }\end{array}$} & \multirow[t]{2}{*}{$\begin{array}{l}\text { Standard } \\
\text { deviation }\end{array}$} & \multicolumn{2}{|c|}{$\begin{array}{c}\text { Confidential } \\
\text { interval }\end{array}$} & \multirow[t]{2}{*}{$\begin{array}{l}\text { Minimum } \\
\text { (months) }\end{array}$} & \multirow[t]{2}{*}{$\begin{array}{c}\text { Maximum } \\
\text { (months) }\end{array}$} & \multirow[t]{2}{*}{ p-value } & \multirow[t]{2}{*}{$\begin{array}{l}\text { Osteoporosis } \\
\text { (N/\%) }\end{array}$} & \multirow[t]{2}{*}{ p-value } \\
\hline & & & & & $5 \%$ & $95 \%$ & & & & & \\
\hline & $\begin{array}{l}\text { No mutation } \\
\text { identified }\end{array}$ & 44 & 211.75 & 217.501 & 145.62 & 277.88 & 25 & 932 & & $8(19 \%)$ & \\
\hline \multirow[t]{2}{*}{$\begin{array}{l}\text { Pancreatic insufficiency + } \\
\text { Pancreatic sufficiency }\end{array}$} & $\begin{array}{c}\text { One CFTR } \\
\text { mutation identified }\end{array}$ & 51 & 201.18 & 165.050 & 154.76 & 247.60 & 11 & 782 & 0.854 & $9(17.6 \%)$ & \\
\hline & $\begin{array}{l}\text { Two mutation } \\
\text { identified }\end{array}$ & 84 & 220.06 & 188.643 & 179.12 & 261.00 & 7 & 1274 & & $12(14.3 \%)$ & 0.761 \\
\hline \multirow[t]{2}{*}{ Pancreatic insufficiency } & $\begin{array}{c}\text { One CFTR } \\
\text { mutation identified }\end{array}$ & 35 & 221.57 & 216.17 & 147.31 & 295.83 & 25 & 932 & & $7(21.2 \%)$ & \\
\hline & $\begin{array}{l}\text { Two mutation } \\
\text { identified }\end{array}$ & 43 & 198.81 & 171.31 & 146.09 & 251.54 & 11 & 782 & 0.940 & $5(11.6 \%)$ & 0.345 \\
\hline
\end{tabular}

CFTR, Cystic fibrosis transmembrane regulator; $\mathrm{N}$, number of patients. 
The PI is an important clinical marker of CF and is considered associated with the severity of disease and severe CFTR mutations (Class I, II and/or III). Studies considering populations of patients with $\mathrm{CF}$, as performed by the Cystic Fibrosis Foundation give the prevalence of PI ranging from 5-10\%. In our study, the high prevalence of PI may be associated with: (i) presence of higher frequency of mutations Class IV, V and/or VI, (ii) presence of modifier genes acting on the symptom of the disease, (iii) high miscegenation could be a protective factor for PI, (iv) environmental factor as an unknown protector.

The PI was used in statistical analysis as factor correction for no determination of CFTR mutation in CF groups with no or one CFTR mutation screened. After the patient exclusion to statistical analysis, all the previous positive associations were negative, except for GSTM1 null allele. The null allele was associated as protector factor for onset of digestive symptoms $(\mathrm{OR}=0.134 ; \mathrm{CI}=0.023-0.606$; Table 2).

One important aspect considered was the age. Before the statistical analysis, the age was considered between the CFTR mutations groups $(p=0.854)$. The same occurred for CFTR mutations groups + insufficiency pancreatic $(p=0.940)$ (Table 6). No positive association was find considering age.

The divergent immune response is associated with multiple factors that denote the CF complexity such as the multigenic response, environmental influences, and interaction between airway microorganisms [49,52]. Clinically severe patients may have high initial inflammatory response, characterizing $\mathrm{CF}$ as a disease where inflammation occurs prior to infection [53]. Polymorphisms in genes that are involved in inflammation may be a risk factor for early severity of the disease [1], and patients with airways colonized by bacteria suffer early clinical deterioration and high levels of airway inflammation [54].

For the same population, a first study taking into account the same polymorphisms and clinical variables was performed. The previous data analyzed the genetic interaction among GST and GCLC polymorphisms, CFTR mutations and clinical markers. The data showed an interaction of GSTM1 and GSTT1 genes deletion, GSTP1* + 313A > G, and CFTR mutations $(\mathrm{p}=0.008)$ and Bhalla clinical score by multifactor dimensionality reduction test. The Bhalla score is a computed tomography, which measures pulmonary involvement, therapeutic effects and selection of patients for transplantation, which detects anatomical changes of the lung parenchyma. The data published showed a first step to understand the complex mechanisms associated with the CF severity and modifier genes [55].

In the present study, we studied a CF population with complex clinical characteristics. By considering the different possible groupings of polymorphisms and clinical variables (Table 7) in relation to the CFTR gene, we performed various association studies. Supplementary data for GCLC-129C > T, GCLC-3506A > G, GSTM1 gene deletion, GSTT1 gene deletion, GSTM1/GSTT1 gene deletions and GSTP1* $+313 \mathrm{~A}>\mathrm{G}$ are shown in Tables 8, 9, 10, 11, 12, 13 and 14. Further multicenter studies should be conducted to verify the influence of modifier genes in different CFTR genotypes.

Study limitations: (i) CFTR mutation with no complete screening; (ii) short population of CF patients; (iii) spirometry test performed by transversal method and did no performed longitudinally; (iv) no measure of GSH activity or GST and GCLC proteins, taking into account the sample collection limitation in our center and time to process

Table 7 Patient characteristics $(n=180)$

\begin{tabular}{|c|c|}
\hline Characteristic & \\
\hline Male gender & $50 \%(90)$ \\
\hline Age (months) & $212 \pm 15.75(7-288)$ \\
\hline Caucasoid & $91.75 \%$ \\
\hline BMI - thinness and accentuated thinness & $22.22 \%(40)$ \\
\hline One class I, II or III identified mutation & $28.33 \%(51)$ \\
\hline Two class I, II or III identified mutations & $47.22 \%(85)$ \\
\hline Age at first clinical manifestation (months) & $35 \pm 8.88(0-156)$ \\
\hline Age at diagnosis (months) & $87 \pm 13.63(0-170.76)$ \\
\hline Age at start of digestive symptoms (months) & $40.6 \pm 9.11(0-149.4)$ \\
\hline Age at start of pulmonary symptoms (months) & $34.8 \pm 9.88(0-1156)$ \\
\hline $\mathrm{SpO} 2(\%)$ & $94.92 \pm 4.26(66-99)$ \\
\hline Bhalla & $8.74 \pm 5.72(0-25)$ \\
\hline Kanga & $18.85 \pm 5.84(10-40)$ \\
\hline Shwachman-Kulczycki & $65.85 \pm 16.77(20-95)$ \\
\hline $\mathrm{FVC}(\%)$ & $79.29 \pm 23.55(19-135)$ \\
\hline $\mathrm{FEV}_{1}(\%)$ & $71.29 \pm 27.467(17-132)$ \\
\hline $\mathrm{FEV}_{1} / \mathrm{FVC}(\%)$ & $83.46 \pm 15.95(37-137)$ \\
\hline $\mathrm{FEF}_{25-75} \%$ & $59.05 \pm 35.55(7-150)$ \\
\hline Nasal polyps & $18.33 \%(33)$ \\
\hline Diabetes mellitus & $18.33 \%(33)$ \\
\hline Osteoporosis & $16.11 \%(29)$ \\
\hline Pancreatic insufficiency & $80.0 \%(144)$ \\
\hline Meconium ileus & $15.00 \%(27)$ \\
\hline Age at first isolated $P$. aeruginosa (months) & $102.6 \pm 14.45(24-180)$ \\
\hline$P$. aeruginosa status ${ }^{a}$ & $56.67 \%(102)$ \\
\hline P. aeruginosa mucoid status ${ }^{a}$ & $42.22 \%(76)$ \\
\hline B. cepacia status ${ }^{\mathrm{a}}$ & $13.88 \%(25)$ \\
\hline A. $x y$ losoxidans status ${ }^{a}$ & $10.00 \%(18)$ \\
\hline S. aureus status ${ }^{a}$ & $78.88 \%(142)$ \\
\hline \multicolumn{2}{|c|}{$\begin{array}{l}\text { Continuous variables expressed as mean } \pm \mathrm{SD} \text { (range). Other data shown as } \\
\text { percentage (number of patients). 'Based on three consecutive positive } \\
\text { respiratory cultures. } \\
\mathrm{N} \text {, Sample size; BMI, Body mass index; } \mathrm{SpO}^{2} \text {, Hemoglobin oxygen saturation in } \\
\text { the blood; FVC, Forced vital capacity; } \mathrm{FEV}_{1} \text {, Forced expiratory volume in the } \\
\text { first second; } \mathrm{FEF}_{25-75} \text {, Forced expiratory flow between } 25 \text { and } 75 \% \text { of FVC. }\end{array}$} \\
\hline
\end{tabular}


Table 8 GCLC-129C > T polymorphism associated with CF clinical variables as distributed by CFTR mutation

\begin{tabular}{|c|c|c|c|c|c|c|c|c|c|c|c|c|}
\hline \multirow[t]{2}{*}{ Variable } & \multicolumn{2}{|c|}{$\begin{array}{l}\text { Without taking CFTR } \\
\text { mutation into account }\end{array}$} & \multicolumn{2}{|c|}{$\begin{array}{c}\text { No CFTR mutations } \\
\text { identified }\end{array}$} & \multicolumn{2}{|c|}{$\begin{array}{l}\text { No CFTR mutations } \\
\text { identified with PI }\end{array}$} & \multicolumn{2}{|c|}{$\begin{array}{l}\text { One identified } \\
\text { CFTR mutation }\end{array}$} & \multicolumn{2}{|c|}{$\begin{array}{c}\text { One identified CFTR } \\
\text { mutation with PI } \\
\end{array}$} & \multicolumn{2}{|c|}{$\begin{array}{l}\text { Two identified } \\
\text { CFTR mutations }\end{array}$} \\
\hline & $p$-value & $p$-corrected & $p$-value & $p$-corrected & $p$-value & $p$-corrected & $p$-value & p-corrected & $p$-value & $p$-corrected & $p$-value & $p$-corrected \\
\hline Gender $^{\mathrm{a}}$ & 0.577 & 1 & 1 & 1 & 1 & 1 & 0.024 & 0.096 & 0.698 & 1 & 0.418 & 1 \\
\hline $\mathrm{Age}^{\mathrm{a}}$ & 0.348 & 1 & 1 & 1 & 0.667 & 1 & 1 & 1 & 1 & 1 & 0.249 & 0.996 \\
\hline Onset of symptoms ${ }^{a}$ & 1 & 1 & 0.165 & 0.660 & 0.401 & 1 & 1 & 1 & 1 & 1 & 0.392 & 1 \\
\hline Onset of pulmonary disease ${ }^{a}$ & 0.162 & 0.648 & 1 & 1 & 1 & 1 & 0.409 & 1 & 0.685 & 1 & 0.168 & 0.672 \\
\hline Onset of digestive disease $\mathrm{e}^{\mathrm{a}}$ & 1 & 1 & 0.142 & 0.568 & 0.354 & 1 & 0.710 & 1 & 0.650 & 1 & 0.583 & 1 \\
\hline Diagnosis $^{a}$ & 1 & 1 & 1 & 1 & 0.405 & 1 & 0.715 & 1 & 0.412 & 1 & 0.764 & 1 \\
\hline $\mathrm{BMI}^{\mathrm{a}}$ & 1 & 1 & 0.414 & 1 & 0.559 & 1 & 0.331 & 1 & 1 & 1 & 1 & 1 \\
\hline Bhalla score ${ }^{b}$ & 0.626 & 1 & 0.47 & 1 & 0.023 & 0.092 & 0.851 & 1 & 0.090 & 0.360 & 0.834 & 1 \\
\hline Kanga score ${ }^{b}$ & 0.277 & 1 & 0.45 & 1 & 0.632 & 1 & 0.687 & 1 & 0.625 & 1 & 0.192 & 0.768 \\
\hline Shwachman-Kulczycki score ${ }^{b}$ & 0.917 & 1 & 0.532 & 1 & 0.041 & 0.164 & 0.405 & 1 & 0.435 & 1 & 0.767 & 1 \\
\hline Nasal polyposis ${ }^{a}$ & 0.811 & 1 & 0.66 & 1 & 0.555 & 1 & 0.332 & 1 & 0.577 & 1 & 0.066 & 0.264 \\
\hline Diabetes mellitus ${ }^{\mathrm{a}}$ & 0.811 & 1 & 1 & 1 & 1 & 1 & 1 & 1 & 0.315 & 1 & 0.505 & 1 \\
\hline Osteoporosis $^{\mathrm{a}}$ & 0.306 & 1 & 1 & 1 & 0.299 & 1 & 0.353 & 1 & 1 & 1 & 0.238 & 0.952 \\
\hline Meconium ileus & 0.792 & 1 & 1 & 1 & 0.576 & 1 & 0.651 & 1 & 0.147 & 0.588 & 0.727 & 1 \\
\hline Pancreatic insufficiency ${ }^{a}$ & 0.063 & 0.252 & 0.267 & 1 & - & - & 0.328 & 1 & & & 1 & 1 \\
\hline $\mathrm{SpO}^{\mathrm{b}}$ & 0.384 & 1 & 0.296 & 1 & 0.078 & 0.312 & 0.124 & 0.496 & 0.864 & 1 & 0.597 & 1 \\
\hline$\overline{\mathrm{FVC}(\%)^{\mathrm{b}}}$ & 0.822 & 1 & 0.828 & 1 & 0.127 & 0.508 & 0.922 & 1 & 0.506 & 1 & 0.597 & 1 \\
\hline $\mathrm{FEV}_{1}(\%)^{\mathrm{b}}$ & 0.598 & 1 & 0.310 & 1 & 0.160 & 0.640 & 0.983 & 1 & 0.510 & 1 & 0.820 & 1 \\
\hline$\overline{\mathrm{FEV}_{1} / \mathrm{FVC}^{\mathrm{b}}}$ & 1 & 1 & 0.109 & 0.436 & 0.386 & 1 & 0.873 & 1 & 0.820 & 1 & 0.170 & 0.680 \\
\hline $\mathrm{FEF}_{25-75} \%^{\mathrm{b}}$ & 0.448 & 1 & 0.044 & 0.176 & 1 & 1 & 0.982 & 1 & 0.767 & 1 & 0.537 & 1 \\
\hline First $P$. aeruginosa $a^{a}$ & 1 & 1 & 1 & 1 & 0.691 & 1 & 0.695 & 1 & 0.361 & 1 & 1 & 1 \\
\hline P. aeruginosa mucoid ${ }^{a}$ & 0.133 & 0.532 & 1 & 1 & 0.689 & 1 & 0.011 & 0.044 & 0.427 & 1 & 1 & 1 \\
\hline P. aeruginosa no mucoid ${ }^{a}$ & 1 & 1 & 1 & 1 & 1 & 1 & 0.266 & 1 & 0.680 & 1 & 0.391 & 1 \\
\hline A. xylosoxidans ${ }^{\mathrm{a}}$ & 0.534 & 1 & 1 & 1 & 1 & 1 & 1 & 1 & 1 & 1 & 1 & 1 \\
\hline S. aureus $^{\mathrm{a}}$ & 0.261 & 1 & 0.093 & 0.372 & 1 & 1 & 1 & 1 & 1 & 1 & 1 & 1 \\
\hline B. cepacia $^{a}$ & 1 & 1 & 1 & 1 & 1 & 1 & 1 & 1 & 0.318 & 1 & 1 & 1 \\
\hline
\end{tabular}

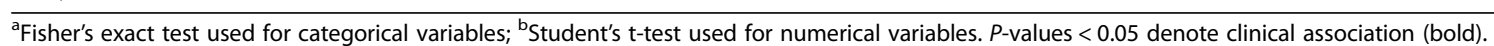

CFTR, Cystic fibrosis transmembrane regulator; PI, Pancreatic insufficiency; GCLC, Glutamate cysteine ligase catalytic subunit; BMI, Body mass index; SpO2, Hemoglobin oxygen saturation in the blood; FVC, Forced vital capacity; FEV $_{1}$, Forced expiratory volume in the first second; FEF, Forced expiratory flow between 25 and $75 \%$ of vital capacity. 
Table 9 GCLC-3506A > G polymorphism in association with CF clinical variables as distributed by CFTR mutation

\begin{tabular}{|c|c|c|c|c|c|c|c|c|c|c|c|c|}
\hline \multirow[t]{2}{*}{ Variable } & \multicolumn{2}{|c|}{$\begin{array}{l}\text { Without taking CFTR } \\
\text { mutation into account }\end{array}$} & \multicolumn{2}{|c|}{$\begin{array}{l}\text { No CFTR mutations } \\
\text { identified }\end{array}$} & \multicolumn{2}{|c|}{$\begin{array}{l}\text { No CFTR mutations } \\
\text { identified with PI }\end{array}$} & \multicolumn{2}{|c|}{$\begin{array}{l}\text { One identified } \\
\text { CFTR mutation }\end{array}$} & \multicolumn{2}{|c|}{$\begin{array}{l}\text { One identified CFTR } \\
\text { mutation with PI }\end{array}$} & \multicolumn{2}{|c|}{$\begin{array}{l}\text { Two identified } \\
\text { CFTR mutations }\end{array}$} \\
\hline & $p$-value & $p$-corrected & $p$-value & p-corrected & $p$-value & $p$-corrected & $p$-value & p-corrected & $p$-value & p-corrected & $p$-value & p-corrected \\
\hline Gender $^{a}$ & 0.753 & 1 & 0.532 & 1 & 1 & 1 & 0.149 & 0.596 & 0.510 & 1 & 0.824 & 1 \\
\hline $\mathrm{Age}^{\mathrm{a}}$ & 0.057 & 0.228 & 0.710 & 1 & 0.245 & 0.980 & 0.541 & 1 & 1 & 1 & 0.339 & 1 \\
\hline Onset of symptoms ${ }^{a}$ & 1 & 1 & 1 & 1 & 0.420 & 1 & 0.731 & 1 & 0.078 & 0.312 & 0.812 & 1 \\
\hline Onset of pulmonary disease ${ }^{a}$ & 0.507 & 1 & 1 & 1 & 0.152 & 0.608 & 0.727 & 1 & 0.302 & 1 & 0.816 & 1 \\
\hline Onset of digestive disease ${ }^{a}$ & 0.865 & 1 & 0.646 & 1 & 0.408 & 1 & 1 & 1 & 0.158 & 0.632 & 1 & 1 \\
\hline Diagnosis $^{a}$ & 0.335 & 1 & 0.419 & 1 & 1 & 1 & 0.330 & 1 & 1 & 1 & 1 & 1 \\
\hline $\mathrm{BMI}^{\mathrm{a}}$ & 1 & 1 & 1 & 1 & 0.281 & 1 & 0.704 & 1 & 0.709 & 1 & 0.785 & 1 \\
\hline Bhalla score $^{b}$ & 0.35 & 1 & 0.830 & 1 & 0.468 & 1 & 0.169 & 0.676 & 0.833 & 1 & 0.495 & 1 \\
\hline Kanga score ${ }^{b}$ & 0.011 & 0.044 & 0.734 & 1 & 0.788 & & 0.067 & 0.268 & 0.588 & 1 & 0.027 & 0.108 \\
\hline Shwachman-Kulczycki score ${ }^{b}$ & 0.091 & 0.364 & 0.725 & 1 & 0.223 & 0.892 & 0.034 & 0.136 & 0.545 & 1 & 0.159 & 0.636 \\
\hline Nasal polyposis ${ }^{a}$ & 0.688 & 1 & 0.251 & 1 & 0.555 & 1 & 0.692 & 1 & 1 & 1 & 0.083 & 0.332 \\
\hline Diabetes mellitus $^{\mathrm{a}}$ & 0.688 & 1 & 1 & 1 & 1 & 1 & 0.419 & 1 & 0.217 & 0.868 & 1 & 1 \\
\hline Osteoporosis $^{\mathrm{a}}$ & 0.133 & 0.532 & 1 & 1 & 0.068 & 0.272 & 0.25 & 1 & 0.630 & 1 & 0.335 & \\
\hline Meconium ileus & 1 & 1 & 1 & 1 & 0.304 & 1 & 1 & 1 & 0.417 & 1 & 1 & 1 \\
\hline Pancreatic insufficiency ${ }^{\mathrm{a}}$ & 0.698 & 1 & 0.180 & 0.720 & - & - & 0.376 & 1 & - & - & 1 & 1 \\
\hline $\mathrm{SpO}^{\mathrm{b}}$ & 0.033 & 0.132 & 0.234 & 0.936 & 0.142 & 0.568 & 0.548 & 1 & 0.134 & 0.536 & 0.149 & 0.596 \\
\hline$\overline{\mathrm{FVC}(\%)^{\mathrm{b}}}$ & 0.412 & 1 & 0.944 & 1 & 0.061 & 0.244 & 0.036 & 0.144 & 0.755 & 1 & 0.955 & 1 \\
\hline $\mathrm{FEV}_{1}(\%)^{\mathrm{b}}$ & 0.166 & 0.664 & 0.877 & 1 & 0.094 & 0.376 & 0.030 & 0.120 & 0.381 & 1 & 0.577 & 1 \\
\hline $\mathrm{FEV}_{1} / \mathrm{FVC}^{\mathrm{b}}$ & 0.054 & 0.216 & 0.912 & 1 & 0.403 & 1 & 0.050 & 0.200 & 0.247 & 0.988 & 0.111 & \\
\hline $\mathrm{FEF}_{25-75} \%^{\mathrm{b}}$ & 0.061 & 0.244 & 0.934 & 1 & 0.177 & 0.708 & 0.029 & 0.116 & 0.577 & 1 & 0.272 & 1 \\
\hline First $P$. aeruginosa $a^{a}$ & 0.350 & 1 & 0.453 & 1 & 0.433 & 1 & 0.716 & 1 & 0.015 & 0.060 & 0.799 & 1 \\
\hline P. aeruginosa mucoid ${ }^{a}$ & 0.152 & 0.608 & 1 & 1 & 0.443 & 1 & 0.064 & 0.256 & 0.178 & 0.712 & 0.371 & 1 \\
\hline P. aeruginosa no mucoid ${ }^{a}$ & 0.057 & 0.228 & 1 & 1 & 0.243 & 0.972 & 0.003 & 0.012 & 0.023 & 0.092 & 0.351 & 1 \\
\hline A. xylosoxidans ${ }^{\mathrm{a}}$ & 0.187 & 0.748 & 0.066 & & 0.044 & 0.176 & 0.565 & 1 & 1 & 1 & 0.343 & 1 \\
\hline S. aureus $^{\mathrm{a}}$ & 0.849 & 1 & 0.708 & 1 & 1 & 1 & 0.376 & 1 & 0.024 & 0.096 & 0.394 & 1 \\
\hline B. cepacia $^{a}$ & 0.246 & 0.984 & 1 & 1 & 1 & 1 & 0.471 & 1 & 0.082 & 0.328 & 0.394 & 1 \\
\hline
\end{tabular}

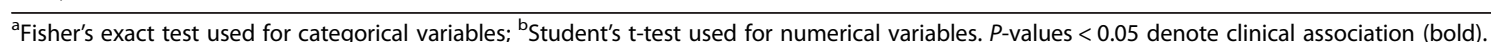

CFTR, Cystic fibrosis transmembrane regulator; GCLC, Glutamate cysteine ligase catalytic subunit; PI, Pancreatic insufficiency; BMI, Body mass index; SpO2, Hemoglobin oxygen saturation in the blood; FVC, Forced vital capacity; $\mathrm{FEV}_{1}$, Forced expiratory volume in the first second; FEF, Forced expiratory flow between 25 and $75 \%$ of vital capacity. 
Table 10 GCLC-129C > T and GCLC-3506A > G polymorphisms by haplotype in association with CF clinical variables as distributed by CFTR mutation

\begin{tabular}{|c|c|c|c|c|c|c|c|c|c|c|c|c|}
\hline \multirow[t]{2}{*}{ Variable } & \multicolumn{2}{|c|}{$\begin{array}{l}\text { Without taking CFTR } \\
\text { mutation into account }\end{array}$} & \multicolumn{2}{|c|}{$\begin{array}{l}\text { No CFTR mutations } \\
\text { identified }\end{array}$} & \multicolumn{2}{|c|}{$\begin{array}{l}\text { No CFTR mutations } \\
\text { identified with PI }\end{array}$} & \multicolumn{2}{|c|}{$\begin{array}{l}\text { One identified } \\
\text { CFTR mutation }\end{array}$} & \multicolumn{2}{|c|}{$\begin{array}{l}\text { One identified CFTR } \\
\text { mutation with PI }\end{array}$} & \multicolumn{2}{|c|}{$\begin{array}{l}\text { Two identified } \\
\text { CFTR mutations }\end{array}$} \\
\hline & $p$-value & $p$-corrected & $p$-value & $p$-corrected & $p$-value & $p$-corrected & $p$-value & $p$-corrected & $p$-value & $p$-corrected & $p$-value & p-corrected \\
\hline Gender $^{a}$ & 0.285 & 1 & 0.302 & 1 & 0.505 & 1 & 0.424 & 1 & 0.479 & 1 & 0.223 & 0.892 \\
\hline $\mathrm{Age}^{\mathrm{a}}$ & 0.437 & 1 & 0.639 & 1 & 0.382 & 1 & 0.601 & 1 & 0.777 & 1 & 0.625 & 1 \\
\hline Onset of symptoms ${ }^{a}$ & 0.098 & 0.392 & 0.407 & 1 & 0.421 & 1 & 0.143 & 0.572 & 0.180 & 0.720 & 0.036 & 0.144 \\
\hline Onset of pulmonary disease ${ }^{a}$ & 0.802 & 1 & 0.091 & 0.364 & 0.163 & 0.652 & 0.424 & 1 & 0.321 & 1 & 0.980 & 1 \\
\hline Onset of digestive disease ${ }^{a}$ & 0.640 & 1 & 0.237 & 0.948 & 0.311 & 1 & 0.692 & 1 & 0.318 & 1 & 0.452 & 1 \\
\hline Diagnosis $^{a}$ & 0.334 & 1 & 0.620 & 1 & 0.637 & 1 & 0.715 & 1 & 0.613 & 1 & 0.218 & 0.872 \\
\hline $\mathrm{BMI}^{\mathrm{a}}$ & 0.620 & 1 & 0.376 & 1 & 0.510 & 1 & 0.848 & 1 & 0.754 & 1 & 0.665 & 1 \\
\hline Bhalla score $^{\text {b }}$ & 0.942 & 1 & 0.808 & 1 & 0.158 & 0.632 & 0.830 & 1 & 0.324 & 1 & 0.311 & 1 \\
\hline Kanga score $^{\text {b }}$ & 0.879 & 1 & 0.884 & 1 & 0.805 & 1 & 0.753 & 1 & 0.745 & 1 & 0.822 & 1 \\
\hline Shwachman-Kulczycki score ${ }^{b}$ & 0.985 & 1 & 0.416 & 1 & 0.151 & 0.604 & 0.538 & 1 & 0.837 & 1 & 0.981 & 1 \\
\hline Nasal polyposis $^{\mathrm{a}}$ & 0.582 & 1 & 0.347 & 1 & 0.285 & 1 & 0.457 & 1 & 0.631 & 1 & 0.986 & 1 \\
\hline Diabetes mellitus ${ }^{a}$ & 0.255 & 1 & 0.858 & 1 & 0.917 & 1 & 0.201 & 0.804 & 0.337 & 1 & 0.383 & 1 \\
\hline Osteoporosis $^{a}$ & 0.562 & 1 & 0.829 & 1 & 0.108 & 0.432 & 0.339 & 1 & 0.036 & 0.144 & 0.713 & 1 \\
\hline Meconium ileus & 0.420 & 1 & 0.389 & 1 & 0.379 & 1 & 0.130 & 0.520 & 0.080 & 0.320 & 0.619 & 1 \\
\hline Pancreatic insufficiency ${ }^{a}$ & 0.159 & 0.636 & 0.398 & 1 & - & - & 0.167 & 0.668 & - & - & 0.601 & 1 \\
\hline $\mathrm{SpO} 2^{\mathrm{b}}$ & 0.506 & 1 & 0.201 & 0.804 & 0.128 & 0.512 & 0.422 & 1 & 0.525 & 1 & 0.278 & 1 \\
\hline $\mathrm{FVC}(\%)^{\mathrm{b}}$ & 0.498 & 1 & 0.216 & 0.864 & 0.121 & 0.484 & 0.738 & 1 & 0.901 & 1 & 0.499 & 1 \\
\hline $\mathrm{FEV}_{1}(\%)^{\mathrm{b}}$ & 0.668 & 1 & 0.214 & 0.856 & 0.201 & 0.804 & 0.479 & 1 & 0.731 & 1 & 0.769 & 1 \\
\hline $\mathrm{FEV}_{1} / \mathrm{FVC}^{\mathrm{b}}$ & 0.615 & 1 & 0.592 & 1 & 0.671 & 1 & 0.407 & 1 & 0.686 & 1 & 0.373 & 1 \\
\hline $\mathrm{FEF}_{25-75} \%^{\mathrm{b}}$ & 0.643 & 1 & 0.326 & 1 & 0.531 & 1 & 0.548 & 1 & 0.942 & 1 & 0.851 & 1 \\
\hline First $P$. aeruginos $a^{a}$ & 0.147 & 0.588 & 0.125 & 0.500 & 0.341 & 1 & 0.146 & 0.584 & 0.027 & 0.108 & 0.264 & 1 \\
\hline P. aeruginosa mucoid ${ }^{a}$ & 0.559 & 1 & 0.316 & 1 & 0.366 & 1 & 0.569 & 1 & 0.285 & 1 & 0.160 & 0.640 \\
\hline P. aeruginosa no mucoid ${ }^{a}$ & 0.319 & 1 & 0.263 & 1 & 0.352 & 1 & 0.276 & 1 & 0.082 & 0.328 & 0.347 & 1 \\
\hline A. xylosoxidans ${ }^{a}$ & 0.327 & 1 & 0.018 & 0.072 & 0.013 & 0.052 & 0.687 & 1 & 0.646 & 1 & 0.006 & 0.024 \\
\hline S. aureus ${ }^{a}$ & 0.843 & 1 & 0.677 & 1 & 0.931 & 1 & 0.049 & 0.196 & 0.032 & 0.128 & 0.466 & 1 \\
\hline B. серасіа ${ }^{a}$ & 0.461 & 1 & 0.734 & 1 & 0.974 & 1 & 0.150 & 0.600 & 0.243 & 0.972 & 0.671 & 1 \\
\hline
\end{tabular}

${ }^{\mathrm{a}}$ Fisher's exact test used for categorical variables: ${ }^{\text {b}}$ Student's t-test used for numerical variables. $P$-values $<0.05$ denote clinical association (bold).

CFTR, Cystic fibrosis transmembrane regulator; GCLC, Glutamate cysteine ligase catalytic subunit; Pl, Pancreatic insufficiency; BMI, Body mass index; SpO2, Hemoglobin oxygen saturation in the blood; FVC, Forced vital capacity; FEV ${ }_{1}$, Forced expiratory volume in the first second; FEF, Forced expiratory flow between 25 and $75 \%$ of vital capacity. 
Table 11 GSTM1 deletion polymorphism in association with CF clinical variables as distributed by CFTR mutation

\begin{tabular}{|c|c|c|c|c|c|c|c|c|c|c|c|c|}
\hline \multirow[t]{2}{*}{ Variable } & \multicolumn{2}{|c|}{$\begin{array}{l}\text { Without taking CFTR } \\
\text { mutation into account }\end{array}$} & \multicolumn{2}{|c|}{$\begin{array}{l}\text { No CFTR mutations } \\
\text { identified }\end{array}$} & \multicolumn{2}{|c|}{$\begin{array}{l}\text { No CFTR mutations } \\
\text { identified with } \mathrm{PI}\end{array}$} & \multicolumn{2}{|c|}{$\begin{array}{l}\text { One identified } \\
\text { CFTR mutation }\end{array}$} & \multicolumn{2}{|c|}{$\begin{array}{c}\text { One identified CFTR } \\
\text { mutation with PI }\end{array}$} & \multicolumn{2}{|c|}{$\begin{array}{l}\text { Two identified } \\
\text { CFTR mutations }\end{array}$} \\
\hline & $p$-value & $p$-corrected & $p$-value & $p$-corrected & $p$-value & $p$-corrected & $p$-value & $p$-corrected & $p$-value & $p$-corrected & $p$-value & $p$-corrected \\
\hline Gender $^{a}$ & 0.171 & 0.684 & 0.764 & 1 & 0.075 & 0.300 & 0.267 & 1 & 0.537 & 1 & 0.110 & 0.440 \\
\hline $\mathrm{Age}^{\mathrm{a}}$ & 1 & 1 & 0.498 & 1 & 0.736 & 1 & 0.579 & 1 & 1 & 1 & 1 & 1 \\
\hline Onset of symptoms ${ }^{a}$ & 0.268 & 1 & 0.459 & 1 & 0.721 & 1 & 1 & 1 & 1 & 1 & 0.629 & 1 \\
\hline Onset of pulmonary disease $^{a}$ & 0.424 & 1 & 0.068 & 0.272 & 1 & 1 & 1 & 1 & 0.742 & 1 & 0.639 & 1 \\
\hline Onset of digestive disease ${ }^{a}$ & 0.409 & 1 & 0.665 & 1 & 1 & 1 & 1 & 1 & 0.008 & 0.032 & 0.635 & 1 \\
\hline Diagnosis $^{a}$ & 1 & 1 & 0.059 & 0.236 & 0.729 & 1 & 0.149 & 0.596 & 1 & 1 & 1 & \\
\hline $\mathrm{BMI}^{\mathrm{a}}$ & 0.462 & 1 & 0.503 & 1 & 0.115 & 0.460 & 0.725 & 1 & 1 & 1 & 0.169 & 0.676 \\
\hline Bhalla score ${ }^{b}$ & 0.86 & 1 & 0.11 & 0.44 & 0.059 & 0.236 & 0.050 & 0.200 & 0.692 & 1 & 0.879 & 1 \\
\hline Kanga score $^{b}$ & 0.982 & 1 & 0.693 & 1 & 0.367 & 1 & 0.822 & 1 & 0.480 & 1 & 0.784 & 1 \\
\hline Shwachman-Kulczycki score ${ }^{b}$ & 0.501 & 1 & 0.449 & 1 & 0.884 & 1 & 0.123 & 0.492 & 0.777 & 1 & 0.568 & 1 \\
\hline Nasal polyposis $^{\mathrm{a}}$ & 0.331 & 1 & 0.136 & 0.544 & 0.610 & 1 & 1 & 1 & 0.407 & 1 & 0.765 & 1 \\
\hline Diabetes mellitus $^{\mathrm{a}}$ & 0.560 & 1 & 1 & 1 & 1 & 1 & 0.703 & 1 & 1 & 1 & 0.169 & 0.676 \\
\hline Osteoporosis $^{\mathrm{a}}$ & 0.217 & 0.868 & 0.435 & 1 & 0.377 & 1 & 0.173 & & 0.633 & 1 & 1 & 1 \\
\hline Meconium ileus & 1 & 1 & 1 & 1 & 0.640 & 1 & 0.726 & 1 & 1 & 1 & 0.776 & 1 \\
\hline Pancreatic insufficiency ${ }^{a}$ & 1 & 1 & 0.765 & 1 & - & - & 1 & 1 & - & - & 1 & 1 \\
\hline $\mathrm{SpO}^{\mathrm{b}}$ & 0.187 & 0.748 & 0.012 & 0.048 & 0.500 & 1 & 0.780 & 1 & 0.652 & 1 & 0.645 & 1 \\
\hline $\mathrm{FVC}(\%)^{\mathrm{b}}$ & 0.990 & 1 & 0.741 & 1 & 0.020 & 0.08 & 0.538 & 1 & 0.307 & 1 & 0.967 & 1 \\
\hline $\mathrm{FEV}_{1}(\%)^{\mathrm{b}}$ & 0.827 & 1 & 0.623 & 1 & 0.030 & 0.012 & 0.786 & 1 & 0.972 & 1 & 0.943 & 1 \\
\hline 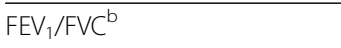 & 0.915 & 1 & 0.749 & 1 & 0.532 & 1 & 0.918 & 1 & 0.244 & 0.976 & 0.597 & 1 \\
\hline $\mathrm{FEF}_{25-75} \%^{\mathrm{b}}$ & 0.853 & 1 & 0.718 & 1 & 0.197 & 0.788 & 0.819 & 1 & 0.255 & 1 & 0.847 & 1 \\
\hline First $P$. aeruginos $a^{a}$ & 0.724 & 1 & 1 & 1 & 0.473 & 1 & 0.056 & 0.224 & 1 & 1 & 0.312 & 1 \\
\hline P. aeruginosa mucoid ${ }^{a}$ & 0.092 & 0.368 & 0.729 & 1 & 0.289 & 1 & 1 & 1 & 0.541 & 1 & 0.107 & 0.428 \\
\hline P. aeruginosa no mucoid ${ }^{a}$ & 0.879 & 1 & 0.754 & 1 & 0292 & 1 & 0.776 & 1 & 1 & 1 & 0.629 & 1 \\
\hline A. xylosoxidans ${ }^{a}$ & 0.619 & 1 & 0.537 & 1 & 1 & 1 & 0.35 & 1 & 0.511 & 1 & 0.52 & 1 \\
\hline S. aureus $^{a}$ & 0.362 & 1 & 0.175 & 0.700 & 0.391 & 1 & 1 & 1 & 1 & 1 & 0.776 & 1 \\
\hline B. cepacia ${ }^{a}$ & 0.371 & 1 & 0.116 & 0.464 & 0.313 & 1 & 0.703 & 1 & 1 & 1 & 1 & 1 \\
\hline
\end{tabular}

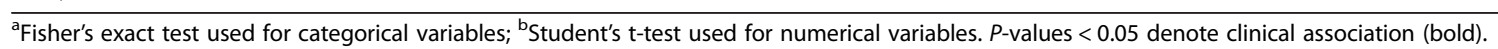

CFTR, Cystic fibrosis transmembrane regulator; GSTM1, Glutathione S-transferase mu 1; Pl, Pancreatic insufficiency; BMI, Body mass index; SpO2, Hemoglobin oxygen saturation in the blood; FVC, Forced vital capacity; $\mathrm{FEV}_{1}$, Forced expiratory volume in the first second; FEF, Forced expiratory flow between 25 and $75 \%$ of vital capacity. 
Table 12 GSTT1 deletion polymorphism in association with CF clinical variables as distributed by CFTR mutation

\begin{tabular}{|c|c|c|c|c|c|c|c|c|c|c|c|c|}
\hline \multirow[t]{2}{*}{ Variable } & \multicolumn{2}{|c|}{$\begin{array}{c}\text { Without taking CFTR } \\
\text { mutation into account }\end{array}$} & \multicolumn{2}{|c|}{$\begin{array}{c}\text { No CFTR mutations } \\
\text { identified }\end{array}$} & \multicolumn{2}{|c|}{$\begin{array}{l}\text { No CFTR mutations } \\
\text { identified with PI }\end{array}$} & \multicolumn{2}{|c|}{$\begin{array}{l}\text { One identified } \\
\text { CFTR mutation }\end{array}$} & \multicolumn{2}{|c|}{$\begin{array}{l}\text { One identified CFTR } \\
\text { mutation with PI }\end{array}$} & \multicolumn{2}{|c|}{$\begin{array}{l}\text { Two identified } \\
\text { CFTR mutations }\end{array}$} \\
\hline & $p$-value & $p$-corrected & $p$-value & $p$-corrected & $p$-value & $p$-corrected & $p$-value & $p$-corrected & $p$-value & $p$-corrected & $p$-value & p-corrected \\
\hline Gender $^{a}$ & 0.211 & 0.844 & 0.778 & 1 & 0.378 & 1 & 1 & 1 & 0.215 & 0.860 & 0.081 & 0.324 \\
\hline $\mathrm{Age}^{\mathrm{a}}$ & 0.043 & 0.166 & 0.750 & 1 & 0.505 & 1 & 0.083 & 0.332 & 0.531 & 1 & 0.795 & 0.795 \\
\hline Onset of symptoms ${ }^{a}$ & 1 & 1 & 0.305 & 1 & 1 & 1 & 0.202 & 0.808 & 0.746 & 1 & 0.600 & 1 \\
\hline Onset of pulmonary disease ${ }^{a}$ & 0.620 & 1 & 0.721 & 1 & 0.229 & 0.916 & 0.521 & 1 & 0.746 & 1 & 0.796 & 1 \\
\hline Onset of digestive disease ${ }^{a}$ & 0.863 & 1 & 0.390 & 1 & 1 & 1 & 0.344 & 1 & 0.179 & 0.716 & 1 & 1 \\
\hline Diagnosis $^{a}$ & 0.745 & 1 & 1 & 1 & 0.303 & 1 & 0.068 & 0.272 & 0.537 & 1 & 0.779 & 1 \\
\hline $\mathrm{BMI}^{\mathrm{a}}$ & 0.447 & 1 & 0.747 & 1 & 0.103 & 0.412 & 0.295 & 1 & 0.728 & 1 & 0.537 & 1 \\
\hline Bhalla score $^{\text {b }}$ & 0.485 & 1 & 0.824 & 1 & 0.134 & 0.536 & 0.322 & 1 & 0.634 & 1 & 0.185 & 0.740 \\
\hline Kanga score ${ }^{\mathrm{b}}$ & 0.737 & 1 & 0.743 & 1 & 0.421 & 1 & 0.953 & 1 & 0.321 & 1 & 0.767 & 1 \\
\hline Shwachman-Kulczycki score ${ }^{b}$ & 0.734 & 1 & 0.984 & 1 & 0.013 & 0.052 & 0.653 & 1 & 0.925 & 1 & 0.393 & 1 \\
\hline Nasal polyposis ${ }^{\mathrm{a}}$ & 0.313 & 1 & 1 & 1 & 1 & 1 & 0.062 & 0.248 & 0.685 & 1 & 1 & 1 \\
\hline Diabetes mellitus $^{\mathrm{a}}$ & 0.158 & 0.632 & 0.115 & 0.460 & 0.398 & 1 & 0.450 & 1 & 0.071 & 0.284 & 0.764 & 1 \\
\hline Osteoporosis $^{a}$ & 1 & 1 & 1 & 1 & 0.085 & 0.340 & 1 & 1 & 0.230 & 0.920 & 0.718 & 1 \\
\hline Meconium ileus & 0.276 & 1 & 0.077 & 0.308 & 0.658 & 1 & 1 & 1 & 0.445 & 1 & 0.335 & 1 \\
\hline Pancreatic insufficiency ${ }^{a}$ & 0.847 & 1 & 0.561 & 1 & - & - & 1 & 1 & - & - & 0.557 & 1 \\
\hline $\mathrm{SaO} 2^{\mathrm{b}}$ & 0.988 & 1 & 0.740 & 1 & 0.170 & 0.680 & 0.595 & 1 & 0.333 & 1 & 0.703 & 1 \\
\hline $\mathrm{FVC}(\%)^{\mathrm{b}}$ & 0.268 & 1 & 0.086 & 0.344 & 0.154 & 0.616 & 0.464 & 1 & 0.412 & 1 & 0.623 & 1 \\
\hline $\mathrm{FEV}_{1}(\%)^{\mathrm{b}}$ & 0.310 & 1 & 0.167 & 0.668 & 0.029 & 0.116 & 0.564 & 1 & 0.597 & 1 & 0.636 & 1 \\
\hline$\overline{\mathrm{FEV}_{1} / \mathrm{FVC}^{\mathrm{b}}}$ & 0.404 & 1 & 0.288 & 1 & 0.017 & 0.068 & 0.692 & 1 & 0.676 & 1 & 0.424 & 1 \\
\hline $\mathrm{FEF}_{25-75} \%^{\mathrm{b}}$ & 0.687 & 1 & 0.390 & 1 & 0.027 & 0.108 & 0.686 & 1 & 0.829 & 1 & 0.959 & 1 \\
\hline First $P$. aeruginos $a^{a}$ & 0.472 & 1 & 1 & 1 & 0.724 & 1 & 0.320 & 1 & 0.713 & 1 & 0.085 & 0.340 \\
\hline P. aeruginosa mucoid ${ }^{a}$ & 0.433 & 1 & 0.747 & 1 & 1 & 1 & 0.393 & 1 & 0.753 & 1 & 1 & 1 \\
\hline P. aeruginosa no mucoid ${ }^{a}$ & 0.876 & 1 & 0.002 & 0.008 & 0.489 & 1 & 0.133 & 0.266 & 0.541 & 1 & 1 & 1 \\
\hline A. $x$ losoxidans ${ }^{a}$ & 0.437 & 1 & 1 & 1 & 0.338 & 1 & 0.623 & 1 & 0.151 & 0.604 & 0.295 & 1 \\
\hline S. aureus $^{a}$ & 0.705 & 1 & 1 & 1 & 0.658 & 1 & 0.325 & 1 & 0.735 & 1 & 1 & 1 \\
\hline B. cepacia $^{a}$ & 1 & 1 & 1 & 1 & 0.177 & 0.708 & 0.699 & 1 & 0.407 & 1 & 0.215 & 0.860 \\
\hline
\end{tabular}

${ }^{\mathrm{a} F i s h e r ' s ~ e x a c t ~ t e s t ~ u s e d ~ f o r ~ c a t e g o r i c a l ~ v a r i a b l e s ; ~}{ }^{\mathrm{b}}$ Student's t-test used for numerical variables. $P$-values $<0.05$ denote clinical association (bold).

CFTR, Cystic fibrosis transmembrane regulator; GSTT1, Glutathione S-transferase theta 1; PI, Pancreatic insufficiency; BMI, Body mass index; SpO2, Hemoglobin oxygen saturation in the blood; FVC, Forced vital capacity; $\mathrm{FEV}_{1}$, Forced expiratory volume in the first second; FEF, Forced expiratory flow between 25 and $75 \%$ of vital capacity. 
Table 13 GSTM1/GSTT1 deletion polymorphism in association with CF clinical variables as distributed by CFTR mutation

\begin{tabular}{|c|c|c|c|c|c|c|c|c|c|c|c|c|}
\hline \multirow[t]{2}{*}{ Variable } & \multicolumn{2}{|c|}{$\begin{array}{l}\text { Without taking CFTR } \\
\text { mutation into account }\end{array}$} & \multicolumn{2}{|c|}{$\begin{array}{l}\text { No CFTR mutations } \\
\text { identified }\end{array}$} & \multicolumn{2}{|c|}{$\begin{array}{l}\text { No CFTR mutations } \\
\text { identified with PI }\end{array}$} & \multicolumn{2}{|c|}{$\begin{array}{l}\text { One identified } \\
\text { CFTR mutation }\end{array}$} & \multicolumn{2}{|c|}{$\begin{array}{l}\text { One identified CFTR } \\
\text { mutation with PI }\end{array}$} & \multicolumn{2}{|c|}{$\begin{array}{l}\text { Two identified } \\
\text { CFTR mutations }\end{array}$} \\
\hline & $p$-value & $p$-corrected & $p$-value & $p$-corrected & $p$-value & $p$-corrected & $p$-value & $p$-corrected & $p$-value & $p$-corrected & $p$-value & p-corrected \\
\hline Gender $^{a}$ & 0.036 & 0.144 & 0.943 & 1 & 0.601 & 1 & 0.369 & 1 & 0.114 & 0.456 & 0.014 & 0.056 \\
\hline $\mathrm{Age}^{\mathrm{a}}$ & 0.331 & 1 & 0.647 & 1 & 0.496 & 1 & 0.054 & 0.216 & 0.149 & 0.596 & 0.908 & 1 \\
\hline Onset of symptoms ${ }^{a}$ & 0.300 & 1 & 0.996 & 1 & 0.835 & 1 & 0.579 & 1 & 0.854 & 1 & 0.049 & 0.196 \\
\hline Onset of pulmonary disease $^{a}$ & 0.588 & 1 & 0.359 & 1 & 0.431 & 1 & 0.776 & 1 & 0.267 & 1 & 0.559 & 1 \\
\hline Onset of digestive disease $\mathrm{e}^{\mathrm{a}}$ & 0.626 & 1 & 0.480 & 1 & 0.581 & 1 & 0.433 & 1 & 0.458 & 1 & 0.051 & 0.204 \\
\hline Diagnosis $^{a}$ & 0.520 & 1 & 0.207 & 0.828 & 0.490 & 1 & 0.710 & 1 & 0.510 & 1 & 0.992 & 1 \\
\hline$\overline{B M l^{a}}$ & 0.283 & 1 & 0.954 & 1 & 0.717 & 1 & 0.252 & 1 & 0.998 & 1 & 0.596 & 1 \\
\hline Bhalla score ${ }^{\mathrm{b}}$ & 0.088 & 0.352 & 0.005 & 0.02 & 0.915 & 1 & 0.381 & 1 & 0.218 & 0.872 & 0.481 & 1 \\
\hline Kanga score $^{\mathrm{b}}$ & 0.885 & 1 & 0.443 & 1 & 0.216 & 0.864 & 0.912 & 1 & 0.261 & 1 & 0.455 & 1 \\
\hline Shwachman-Kulczycki score ${ }^{b}$ & 0.627 & 1 & 0.144 & 0.576 & 0.087 & 0.348 & 0.387 & 1 & 0.104 & 0.416 & 0.195 & 0.780 \\
\hline Nasal polyposis ${ }^{\mathrm{a}}$ & 0.098 & 0.392 & 0.483 & 1 & 0.699 & 1 & 0.467 & 1 & 0.362 & 1 & 0.102 & 0.408 \\
\hline Diabetes mellitus ${ }^{a}$ & 0.259 & 1 & 0.240 & 0.96 & 0.790 & 1 & 0.992 & 1 & 0.555 & 1 & 0.334 & 1 \\
\hline Osteoporosis & 0.204 & 0.816 & 0.501 & 1 & 0.525 & 1 & 0.427 & 1 & 0.187 & 0.748 & 0.386 & 1 \\
\hline Meconium ileus & 0.683 & 1 & 0.266 & 1 & 0.348 & 1 & 0.517 & 1 & 0.905 & 1 & 0.626 & 1 \\
\hline Pancreatic insufficiency ${ }^{\mathrm{a}}$ & 0.965 & 1 & 0.791 & 1 & - & - & 0.975 & 1 & - & - & 0.653 & 1 \\
\hline $\mathrm{SpO}^{\mathrm{b}}$ & 0.449 & 1 & 0.021 & 0.084 & 0.557 & 1 & 0.616 & 1 & 0.774 & 1 & 0.786 & 1 \\
\hline$\overline{\mathrm{FVC}(\%)^{\mathrm{b}}}$ & 0.576 & 1 & 0.518 & 1 & 0.859 & 1 & 0.928 & 1 & 0.475 & 1 & 0.758 & 1 \\
\hline $\mathrm{FEV}_{1}(\%)^{\mathrm{b}}$ & 0.778 & 1 & 0.182 & 0.728 & 0.977 & 1 & 0.799 & 1 & 0.827 & 1 & 0.657 & 1 \\
\hline$\overline{\mathrm{FEV}_{1} / \mathrm{FVC}^{\mathrm{b}}}$ & 0.178 & 1 & 0.007 & 0.028 & 0.265 & 1 & 0.789 & 1 & 0.395 & 1 & 0.593 & 1 \\
\hline $\mathrm{FEF}_{25-75} \%^{\mathrm{b}}$ & 0.881 & 1 & 0.014 & 0.056 & 0.751 & 1 & 0.719 & 1 & 0.370 & 1 & 0.382 & 1 \\
\hline First $P$. aeruginosa $a^{a}$ & 0.545 & 1 & 0.686 & 1 & 0.295 & 1 & 0.019 & 0.076 & 0.299 & 1 & 0.123 & 0.492 \\
\hline P. aeruginosa mucoid ${ }^{\mathrm{a}}$ & 0.134 & 0.536 & 0.118 & 0.472 & 0.492 & 1 & 0.575 & 1 & 0.940 & 1 & 0.337 & 1 \\
\hline P. aeruginosa no mucoid ${ }^{a}$ & 0.487 & 1 & 0.051 & 0.204 & 0.682 & 1 & 0.167 & 0.668 & 0.190 & 0.760 & 0.847 & 1 \\
\hline A. xylosoxidans ${ }^{a}$ & 0.541 & 1 & 0.779 & 1 & 0.663 & 1 & 0.079 & 1 & 0.537 & 1 & 0.995 & 1 \\
\hline S. aureus $^{a}$ & 0.660 & 1 & 0.243 & 0.972 & 0.839 & 1 & 0.716 & 1 & 0.181 & 0.724 & 0.667 & 1 \\
\hline B. cepacia ${ }^{a}$ & 0.861 & 1 & 0.142 & 0.568 & 0.054 & 1 & 0.759 & 1 & 0.145 & 0.580 & 0.640 & 1 \\
\hline
\end{tabular}

aFisher's exact test used for categorical variables; ${ }^{b}$ Student's t-test used for numerical variables. $P$-values $<0.05$ denote clinical association (bold).

CFTR, Cystic fibrosis transmembrane regulator; GSTM1, Glutathione S-transferase mu 1; GSTT1, Glutathione S-transferase theta 1; PI, Pancreatic insufficiency; BMI, Body mass index; SpO2, Hemoglobin oxygen saturation

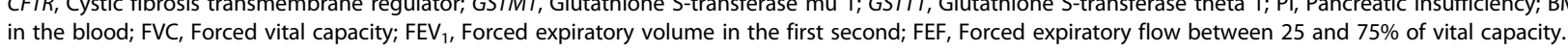


Table 14 GSTP1 + 313A > G polymorphism in association with CF clinical variables as distributed by CFTR mutation

\begin{tabular}{|c|c|c|c|c|c|c|c|c|c|c|c|c|}
\hline \multirow[t]{2}{*}{ Variable } & \multicolumn{2}{|c|}{$\begin{array}{l}\text { Without taking CFTR } \\
\text { mutation into account }\end{array}$} & \multicolumn{2}{|c|}{$\begin{array}{c}\text { No CFTR mutations } \\
\text { identified }\end{array}$} & \multicolumn{2}{|c|}{$\begin{array}{l}\text { No CFTR mutations } \\
\text { identified with PI }\end{array}$} & \multicolumn{2}{|c|}{$\begin{array}{l}\text { One identified } \\
\text { CFTR mutation }\end{array}$} & \multicolumn{2}{|c|}{$\begin{array}{c}\text { One identified CFTR } \\
\text { mutation with PI }\end{array}$} & \multicolumn{2}{|c|}{$\begin{array}{l}\text { Two identified } \\
\text { CFTR mutations }\end{array}$} \\
\hline & $p$-value & $p$-corrected & $p$-value & $p$-corrected & $p$-value & $p$-corrected & $p$-value & $p$-corrected & $p$-value & $p$-corrected & $p$-value & $p$-corrected \\
\hline Gender $^{a}$ & 0.550 & 1 & 0.396 & 1 & 1 & 1 & 0.267 & 1 & 0.763 & 1 & 0.184 & 0.736 \\
\hline$\overline{\text { Age }^{a}}$ & 0.011 & 0.044 & 0.750 & 1 & 0.500 & 1 & 0.051 & 0.204 & 1 & 1 & 0.058 & 0.232 \\
\hline Onset of symptoms ${ }^{a}$ & 0.876 & 1 & 0.473 & 1 & 0.720 & 1 & 1 & 1 & 0.531 & 1 & 1 & 1 \\
\hline Onset of pulmonary disease ${ }^{a}$ & 0.754 & 1 & 0.729 & 1 & 0.252 & 1 & 0.757 & 1 & 0.757 & 1 & 1 & 1 \\
\hline Onset of digestive disease $\mathrm{a}^{\mathrm{a}}$ & 0.516 & 1 & 1 & 1 & 0.462 & 1 & 0.761 & 1 & 1 & 1 & 1 & 1 \\
\hline Diagnosis $^{\mathrm{a}}$ & 0.644 & 1 & 0.694 & 1 & 0.185 & 0.740 & 0.561 & 1 & 0.763 & 1 & 0.441 & 1 \\
\hline $\mathrm{BMI}^{\mathrm{a}}$ & 0.856 & 1 & 0.331 & 1 & 1 & 1 & 1 & 1 & 0.488 & 1 & 1 & 1 \\
\hline Bhalla score ${ }^{b}$ & 0.098 & 0.392 & 0.187 & 1 & 0.671 & 1 & 0.491 & 1 & 0.098 & 0.392 & 0.392 & 1 \\
\hline Kanga score ${ }^{\mathrm{b}}$ & 0.716 & 1 & 0.867 & 1 & 0.604 & 1 & 0.407 & 1 & 0.416 & 1 & 0.300 & 1 \\
\hline Shwachman-Kulczycki score ${ }^{b}$ & 0.554 & 1 & 0.984 & 1 & 0.121 & 0.484 & 0.73 & 1 & 0.198 & 0.792 & 0.170 & 0.680 \\
\hline Nasal polyposis ${ }^{a}$ & 0.848 & 1 & 0.306 & 1 & 0.601 & 1 & 1 & 1 & 0.412 & 1 & 0.562 & 1 \\
\hline Diabetes mellitus $^{a}$ & 0.336 & 1 & 1 & 1 & 1 & 1 & 0.703 & 1 & 1 & 1 & 0.582 & 1 \\
\hline Osteoporosis $^{a}$ & 0.159 & 0.318 & 0.715 & 0.953 & & & 1 & 1 & 0.345 & 1 & 0.009 & 0.036 \\
\hline Meconium ileus & 0.403 & 1 & 1 & 1 & 0.398 & 1 & 1 & 1 & 0.457 & 1 & 0.161 & 0.644 \\
\hline Pancreatic insufficiency ${ }^{a}$ & 0.581 & 1 & 0.393 & 1 & 0.187 & 0.748 & 0.703 & 1 & - & - & 0.578 & 1 \\
\hline $\mathrm{SpO}^{\mathrm{b}}$ & 0.967 & 1 & 0.839 & 1 & 0.230 & 0.920 & 0.156 & 0.624 & 0.157 & 0.628 & 0.346 & 1 \\
\hline$\overline{\mathrm{FVC}(\%)^{\mathrm{b}}}$ & 0.441 & 1 & 0.407 & 1 & 0.279 & 1 & 0.849 & 1 & 0.315 & 1 & 0.626 & 1 \\
\hline$\overline{F E V_{1}(\%)^{\mathrm{b}}}$ & 0.338 & 1 & 0.467 & 1 & 0.923 & 1 & 0.907 & 1 & 0.221 & 0.884 & 0.451 & 1 \\
\hline$\overline{\mathrm{FEV}_{1} / \mathrm{FVC}^{\mathrm{b}}}$ & 0.295 & 1 & 0.265 & 1 & 0.218 & 0.872 & 0.575 & 1 & 0.771 & 1 & 0.439 & 1 \\
\hline$\overline{\mathrm{FEF}} 25-75 \%^{\mathrm{b}}$ & 0.146 & 0.584 & 0.498 & 1 & 0.261 & 1 & 0.505 & 1 & 0.379 & 1 & 0.291 & 1 \\
\hline First $P$. aeruginosa $a^{a}$ & 0.035 & 0.140 & 1 & 1 & 0.473 & 1 & 0.056 & 0.224 & 1 & 1 & 0.203 & 0.812 \\
\hline P. aeruginosa mucoid ${ }^{\mathrm{a}}$ & 0.289 & 1 & 0.331 & 1 & 0.505 & 1 & 0.782 & 1 & 0.760 & 1 & 0.653 & 1 \\
\hline P. aeruginosa no mucoid ${ }^{a}$ & 1 & 1 & 0.548 & 1 & 1 & 1 & 0.776 & 1 & 0.760 & 1 & 0.482 & 1 \\
\hline A. xylosoxidans ${ }^{a}$ & 0.806 & 1 & 0.196 & 0.784 & 1 & 1 & 0.350 & 1 & 0.488 & 1 & 0.755 & 1 \\
\hline S. aureus ${ }^{a}$ & 0.721 & 1 & 0.507 & 1 & 1 & 1 & 0.743 & 1 & 0.185 & 0.740 & 0.565 & 1 \\
\hline B. cepacia ${ }^{a}$ & 0.667 & 1 & 0.196 & 0.784 & 1 & 1 & 0.703 & 1 & 0.698 & 1 & 0.404 & 1 \\
\hline
\end{tabular}

${ }^{\mathrm{a} F i s h e r ' s ~ e x a c t ~ t e s t ~ u s e d ~ f o r ~ c a t e g o r i c a l ~ v a r i a b l e s ; ~}{ }^{\mathrm{b}}$ Student's t-test used for numerical variables. $P$-values $<0.05$ denote clinical association (bold).

CFTR, Cystic fibrosis transmembrane regulator; GSTP1, Glutathione S-transferase pi 1; PI, Pancreatic insufficiency; BMI, Body mass index; SpO2, Hemoglobin oxygen saturation in the blood; FVC, Forced vital capacity; FEV ${ }_{1}$, Forced expiratory volume in the first second; FEF, Forced expiratory flow between 25 and $75 \%$ of vital capacity. 
all data. Study highlights the data by: (i) one CF center collection - considering an admixed population, the CF patients from one center minimizes miscegenation factors. Another fact, is the similar environmental and the same access to treatment; (ii) high number of clinical markers evaluated provides better association and characterization of modifier genes action; (iii) complete CF diagnosis performed by different methods.

\section{Conclusions}

Our results show that, although a monogenic disease, CF is heavily influenced in its clinical characteristics, evolution and severity by polymorphisms in modifier genes. Nevertheless, there is still a long way before the dynamics of polymorphisms in genes active in the GSH metabolic pathway and involved in detoxification in CF are fully understood.

Another fact is the prevalence of PS and PI that should be considered in all studies in the future, being associated with different phenotype and genotype.

\section{Abbreviations}

CF: Cystic fibrosis; CFTR: Cystic fibrosis transmembrane regulator; GCLC: Glutamate-cysteine ligase, catalytic subunit; GST: Glutathione S-transferase; GSTM1: Glutathione S-transferase mu 1; GSTT1: Glutathione S-transferase tetha 1; GSTP1: Glutathione S-transferase pi 1; NMPA: No mucoid Pseudomonas aeruginosa; SpO2: Transcutaneous hemoglobin oxygen saturation; FEV1\%: Forced expiratory volume in 1 second; FVC: Forced vital capacity; FEF $25-75 \%$ : Forced expiratory flow 25-75\%; BMI: Body mass index; WHO: World health organization; MLPA: Multiplex ligation-dependent probe amplification; PCR: Polymerase chain reaction; SPSS: Statistical package for social science for windows; PS: Pancreatic sufficiency; PI: Pancreatic insufficiency; COPD: Chronic obstructive pulmonary disease.

\section{Competing interests}

The authors declare that they have no competing interests.

\section{Authors' contributions}

FALM contributed to the study conception and design, acquired, analyzed and interpreted the data, drafted the manuscript and revised it for intellectual content. CSB carried out the molecular genetic studies and drafted the manuscript. AFR drafted the manuscript and revised it for intellectual content. JDR approved the manuscript for publication. All authors read and approved the final manuscript.

\section{Acknowledgements}

We thank Luciana Cardoso Bonadia, Taís Daiene Russo Hortencio, Kátia Cristina Alberto Aguiar, Aline Gonçalves and Simoni Avansini for assistance in data collection and organization of ideas, Rodrigo Secolin for reviewing the use of English, and Maria Angela Ribeiro for spirometry analysis. Frauk Stanke, Andreas Hector and Harriet Corvol to manuscript correction. Margarida do Amaral and Karl Kunzelmann to provide CFTR-activity analysis.

Received: 4 February 2013 Accepted: 17 February 2014 Published: 4 March 2014

\section{References}

1. Cutting GR: Modifier genes in Mendelian disorders: the example of cystic fibrosis. Ann N Y Acad Sci 2010, 1214:57-69.

2. Collaco JM, Blackman SM, McGready J, Naughton KM, Cutting GR: Quantification of the relative contribution of environmental and genetic factors to variation in cystic fibrosis lung function. J Pediatr 2010, 157:802-807.

3. Simmonds NJ, MacNeil SJ, Cullinan P, Hodson ME: Cystic fibrosis and survival to 40 years: a case-control study. Eur Respir J 2010, 36:1277-1283.
4. Matel $\mathrm{L}$, Milla CE: Nutrition in cystic fibrosis. Semin Respir Crit Care Med 2009, 30:579-586.

5. Casier A, Goubert L, Theunis M, Huse D, Baets F, Matthys D, Crombez G: Acceptance and well-being in adolescents and young adults with cystic fibrosis: a prospective study. J Ped Psychol 2011, 36:476-487.

6. Stanke F, Becker T, Kumar V, Hedtfeld S, Becker C, Cuppens H, Tamm S, Yarden J, Laabs U, Siebert B, Fernandez L, Macek M Jr, Radojkovic D, Ballmann M, Greipel J, Cassiman JJ, Wienker TF, Tümmler B: Genes that determine immunology and inflammation modify the basic defect of impaired ion conductance in cystic fibrosis epithelia. J Med Genet 2011, 48:24-31.

7. Merlo CA, Boyle MP: Modifier genes in cystic fibrosis lung disease. J Lab Clin Med 2003, 141:237-242.

8. Slieker MG, Sanders EAM, Rijkers GT, Ruven HJT, Van Der Ent CK: Disease modifying genes in cystic fibrosis. J Cyst Fibros 2005, 4:7-13.

9. Davies JC, Griesenbach U, Alton E: Modifier genes in cystic fibrosis. Pediatr Pulmonol 2005, 39:383-391.

10. Faria EJ, Faria IC, Ribeiro JD, Ribeiro AF, Hessel G, Bertuzzo CS: Association of MBL2, TGF-beta1 and CD14 gene polymorphisms with lung disease severity in cystic fibrosis. J Bras Pneumol 2009, 35(4):334-342.

11. Marson FAL, Bertuzzo CS, Hortencio TD, Ribeiro JD, Bonadia LC, Ribeiro AF: The $A C E$ gene $D / /$ polymorphism as a modulator of severity of cystic fibrosis. BMC Pulm Med 2012, 12:41.

12. Marson FAL, Bertuzzo CS, Ribeiro AF, Ribeiro JD: Polymorphisms in ADRB2 gene can modulate the response to bronchodilators and the severity of cystic fibrosis. BMC Pulm Med 2012, 12(1):50.

13. Furgeri DT, Marson FAL, Ribeiro AF, Bertuzzo CS: Association between the IVS4G > T mutation in the TCF7L2 gene and susceptibility to diabetes in cystic fibrosis patients. BMC Res Notes 2012, 5:561.

14. Marson FAL, Rezende LM, Furgeri DT, Ribeiro AF, Ribeiro JD, Bertuzzo CS: ADRA2A is a Cystic Fibrosis Modifier Gene. Int J Genet 2013, 5(1):125-131.

15. Marson FAL, Marcelino ARB, Ribeiro AF, Ribeiro JD, Bertuzzo CS: COX-2 Gene Polymorphisms: Genetic Determinants of Cystic Fibrosis Comorbidities. Int J Genet 2013, 5(1):132-138.

16. Marson FAL, Marcelino ARB, Rezende LM: The IFRD1 (57460C > T polymorphism) gene: a negative report in cystic fibrosis clinical severity. J Mol Genet Med 2013. in press.

17. Liu S, Li B, Zhou Y, Zhong N, Ran P: Genetic analysis of CC16, OGG1 and GCLC polymorphisms and susceptibility to COPD. Respirology 2007, 12:29-33.

18. Galli F, Battistoni A, Gambari R, Pompella A, Bragonzi A, Pilolli F, luliano L, Piroddi M, Dechecchi MC, Cabrini G, Working Group on Inflammation in Cystic Fibrosis: Oxidative stress and antioxidant therapy in cystic fibrosis. Biochim Biophys Acta 2012, 1822(5):690-713.

19. Henrion-Caude A, Flamant C, Roussey M, Housset C, Flahault A, Fryer AA, Chadelat K, Strange RC, Clement A: Liver disease in pediatric patients with cystic fibrosis is associated with glutathione S-transferase P1 polymorphism. Hepatology 2002, 36:913-917.

20. McKone EF, Shao J, Frangolias DD, Keener CL, Shephard CA, Farin FM, Tonelli MR, Pare PD, Sandford AJ, Aitken ML, Kavanagh TJ: Variants in the glutamate-cysteine-ligase gene are associated with cystic fibrosis lung disease. Am J Resp Crit Care Med 2006, 174:415-429.

21. Feuillet-Fieux MN, Nguyen-Khoa T, Loriot MA, Kelly M, De Villartay P, Sermet I, Verrier P, Bonnefont JP, Beaune P, Lenoir G, Lacour B: Glutathione S-transferases related to $P$. aeruginosa lung infection in cystic fibrosis children: preliminary study. Clin Biochem 2009, 42:57-63.

22. Strange RC, Spiteri MA, Ramachandran S, Fryer AA: Glutathione-S-transferase family of enzymes. Mutat Res 2001, 482:21-26.

23. National Center for Biotechnology Information. In [http://www.ncbi.nlm. nih.gov/]

24. Amorim LMF, Rossini A, Mendonça G, Lotsch P, Simão TA, Gallo CM, Pinto L: CYP1A1, GSTM1, and GSTT1 polymorphisms and breast cancer risk in Brazilian women. Cancer Lett 2002, 181:179-186.

25. Baranov VS, Ivaschenko T, Bakay B, Aseev M, Belotserkovskaya R, Baranova H, Malet P, Perriot J, Mouraire P, Baskakov VN, Savitskyi GA, Gorbushin S, Deyneka SI, Michnin E, Barchuck A, Vakharlovsky V, Pavlov G, Shilko VI, Guembitzkaya T, Kovaleva L: Proportion of the GSTM1 0/0 genotype in some Slavic populations and its correlation with cystic fibrosis and some multifactorial diseases. Hum Genet 1996, 97:516-520.

26. Hull J, Thomson AH: Contribution of genetic factors other than CFTR to disease severity in cystic fibrosis. Thorax 1998, 53:1018-1021. 
27. Harries LW, Stubbins MJ, Forman D, Howard GCW, Wolf CR: Identification of genetic polymorphisms at the glutathione S-transferase Pi locus and association with susceptibility to bladder, testicular and prostate cancer. Carcinogenesis 1997, 18:641-644.

28. Koide S, Kugiyama K, Sugiyama S, Nakamura S, Fukushima H, Honda O, Yoshimura M, Ogawa H: Association of polymorphism in glutamate-cysteine ligase catalytic subunit gene with coronary vasomotor dysfunction and myocardial infarction. J Am Coll Cardiol 2003, 41:539-545.

29. Hudson VM: Rethinking cystic fibrosis pathology: the critical role of abnormal reduced glutathione (GSH) transport caused by CFTR mutation. Free Radic Biol Med 2001, 1530:1440-1461.

30. Collaco JM, Cutting GR: Update on gene modifiers in cystic fibrosis. Curr Opin Pulm Med 2008, 14:559-566.

31. Santos CIS, Ribeiro JD, Ribeiro AF, Hessel G: Critical analysis of scoring systems used in the assessment of cystic fibrosis severity: state of the art. J Bras Pneumol 2004, 30:286-298.

32. Döring G, Flume P, Heijerman H, Elborn JS, Consensus Study Group: Treatment of lung infection in patients with cystic fibrosis: current and future strategies. J Cyst Fibros 2012, 11(6):461-479.

33. American Thoracic Society (ATS). In http://www.thoracic.org/.

34. Polgar G, Promadhat V: Pulmonary function testing in children: techniques and Standards. Philadelphia, PA: WB Saunders Company; 1971.

35. Quanjer PH, Stanojevic S, Cole TJ, Baur X, Hall GL, Culver BH, Enright PL, Hankinson JL, Ip MS, Zheng J, Stocks J: ERS Global Lung Function Initiative: multi-ethinic values for spirometry for the 3-95yr age range: the global lung function 2012 equations. Eur Respir J 2012, 40:1324-1343.

36. Abdel-Rahman SZ, El-Zein RA, Anwar WA, Au WW: A multiplex PCR procedure for polymorphic analysis of GSTM1 e GSTT1 genes in population studies. Cancer Lett 1996, 107:229-233.

37. Dean AG, Dean JA, Coulombier D, Brendel KA, Smith DC, Burton AH, Dicker RC, Sullivan K, Fagan RF, Arner TG: EPI Info, Version 6.0: a word processing database and statistics program for epidemiology on microcomputers. Atlanta, Georgia: Center of Disease Control and Prevention; 1994.

38. Faul F, Erdfelde E, Lang AG, Buchner A: GPower 3: a flexible statistical power analysis program for the social, behavioral, and biomedical sciences. Behav Res Meth 2007, 39:175-191.

39. Drăghici S: Data analysis tools for DNA microarrays. New York: Chapman \& Hall/CRC; 2003.

40. Drumm ML, Ziady AG, Davis PB: Genetic variation and clinical heterogeneity in cystic fibrosis. Annu Rev Pathol 2012, 7:267-282.

41. Ghezzi P: Role of glutathione in immunity and inflammation in the lung. Int J Gen Med 2011, 4:105-113.

42. Hayes JD, Pulford DJ: The glutathione S-transferase supergene family: regulation of GST and the contribution of the isoenzymes to cancer chemoprotection and drug resistance. Crit Rev Biochem Mol Biol 1995, 30:445-600

43. Gresner P, Gromadzinska J, Wasowicz W: Polymorphism of selected enzymes involved in detoxification and biotransformation in relation to lung cancer. Lung Cancer 2007, 57:1-25.

44. Gilliland FD, Gauderman WJ, Vora H, Rappaport E, Dubeau L: Effects of glutathione-S-transferase M1, T1, and P1 on childhood lung function growth. Am J Respir Crit Care Med 2002, 166:710-716.

45. Campolo J, Penco S, Bianchi E, Colombo L, Parolini M, Caruso R, Sedda V, Patrosso MC, Cighetti G, Marocchi A, Parodi O: Glutamate-cysteine ligase polymorphism, hypertension, and male sex are associated with cardiovascular events. Biochemical and genetic characterization of Italian subpopulation. Am Heart J 2007, 154:1123-1130.

46. Döring G, Conway SP: Osteoporosis in cystic fibrosis. J Pediatr 2008, 84:1-3.

47. Gould NS, Min E, Martin RJ, Day BJ: CFTR is the primary known apical glutathione transporter involved in cigarette smoke-induced adaptive responses in the lung. Free Radic Biol Med 2012, 52(7):1201-1206.

48. Korytina GF, Yanbaeva DG, Victorova TV: Polymorphism of glutathione S-transferase M1 and P1 in patients with cystic fibrosis and chronic respiratory diseases. Russ J Genet 2004, 40:314-320.

49. Park JE, Yung R, Stefanowicz D, Shumansky K, Akhabir L, Durie PR, Corey M, Zielenski J, Dorfman R, Daley D, Sandford AJ: Cystic fibrosis modifier genes related to Pseudomonas aeruginosa infection. Genes Immun 2011, 12:370-377.

50. Mitrunen K, Jourenkova N, Kataja V, Eskelinen M, Kosma VM, Benhamou S, Vainio H, Uusitupa M, Hirvonen A: Glutathione S-transferase M1, M3, P1, and $\mathrm{T} 1$ genetic polymorphisms and susceptibility to breast cancer. Cancer Epidemiol Biomarkers Prev 2001, 10:229-236.
51. Goloni-Bertollo EM, Biselli JM, Corrêa LCL, Maníglia JV, Rossit ARB, Ruiz MT, Pavarino-Bertelli EC: Avaliação da influência da nulidade dos genótipos GSTT1 e GSTM1 na carcinogênese em cabeça e pescoço. Rev Assoc Med Bras 2006, 52:365-368.

52. Guss AM, Roeselers G, Newton ILG, Young CR, Klepac-Ceraj V, Lory S, Cavanaugh CM: Phylogenetic and metabolic diversity of bacteria associated with cystic fibrosis. ISME J 2011, 5:20-29.

53. Balough K, McCubbin M, Weinberger M, Smits W, Ahrens R, Fick R: The relationship between infection and inflammation in the early stages of lung disease from cystic fibrosis. Pediatr Pulmonol 1995, 20:63-70.

54. Sagel SD, Gibson RL, Emerson J, McNamara S, Burns JL, Wagener JS, Ramsey BW, Inhaled Tobramycin in Young Children Study Group; Cystic Fibrosis Foundation Therapeutics Development Network: Impact of Pseudomonas and Staphylococcus infection on inflammation and clinical status in young children with cystic fibrosis. J Pediatr 2009, 154:183-188.

55. Marson FAL, Bertuzzo CS, Secolin R, Ribeiro AF, Ribeiro JD: Genetic interaction of GSH metabolic pathway genes in cystic fibrosis. BMC Med Genet 2013, 10(14):60.

doi:10.1186/1471-2350-15-27

Cite this article as: Marson et al.: Polymorphisms in the glutathione pathway modulate cystic fibrosis severity: a cross-sectional study. BMC Medical Genetics 2014 15:27.

\section{Submit your next manuscript to BioMed Central and take full advantage of:}

- Convenient online submission

- Thorough peer review

- No space constraints or color figure charges

- Immediate publication on acceptance

- Inclusion in PubMed, CAS, Scopus and Google Scholar

- Research which is freely available for redistribution 